\title{
Application of SWAT (Soil and Water Assessment Tool) to the Abay River Basin of Ethiopia: The Case of Didessa Sub Basin
}

\author{
Timketa Adula Duguma \\ 1 Department of Agricultural and Bioprocess Engineering, Ambo University Institute of \\ Technology, West shoa, Ambo, Ethiopia; aucEthiopia@ethionet.et \\ * Correspondence: timketa.adula@ambou.edu.et; Tel.: +251910182498
}

\begin{abstract}
In this study the semi-distributed model SWAT (Soil and Water Assessment Tool), were applied to evaluate stream flow of Didessa sub basin, which is one of the major sub basins in Abay river basin of Ethiopia. The study evaluated the quality of observed meteorological and hydrological data, established SWAT hydrological model, identified the most sensitive parameters, evaluated the best distribution for flow and developed peak flow for major tributary in the sub basin. The result indicated that the SWAT model developed for the sub basin evaluated at multi hydro-gauging stations and its performance certain with the statistical measures, coefficient about determination $\left(R^{2}\right)$ and also Nash coefficient (NS) with values ranging 0.62 to 0.8 and 0.6 to 0.8 respectively at daily time scale. The values of $\mathrm{R}^{2}$ and NS increases at monthly time scale and found ranging 0.75 to 0.92 and 0.71 to 0.91 respectively. Sensitivity analysis is performed to identify parameters those were most sensitive for the sub basin. CN2, GWQMN, CH_K, ALPHA_BNK and LAT_TIME are the most sensitive parameters in the sub basin. Finally, the peak flow for 2-10000 returns periods were determined after the best probability distribution is identified in EasyFit computer program.
\end{abstract}

Keywords: Didessa Sub basin; SWAT; Simulated Stream flow

\section{Introduction}

Hydrological models have been widely applied for comprehending hydrological process within the catchment since the last decades[5, 1]. The models are tools that depict the physical process regulating the conversion of precipitation to stream flow and to represent the catchment process in a simplified way. There are various hydrological models designed to simulate the relationship between rainfall and runoff under different temporal and spatial dimensions. The focus of these models will be to set a relationship between different hydrological components such as precipitation, evapotranspiration, surface runoff, ground water movement. Hence, hydrological models required on a plan must be more robust, and transparent as they would progressively depend on to make informed decisions on sharing and management of limited water resources $[2,3]$. They consider the spatial and temporal changes of different factors $[4,6]$. Physically based distributed watershed models play a major role in analyzing the impact of land management practices on water, sediment, and agricultural chemical yields in large complex watersheds.

The Soil and Water Assessment Tool, a physically-based, semi-distributed, continuous simulation model, is a guaranteeing model which has been broadly used to comprehend water quantity and quality issues over a wide range of watershed scales and environmental conditions $[23,27,44-45]$. Also, Soil and Water assessment Tool may be a river basin model formed in order to foresee the effect of land management practices on water, sediment, also agricultural substance yields, complex watershed of uneven soils, land use, and management situations for long duration of time. This model has been computationally efficient and easily makes use of available inputs data and enables clients to consider long-term effects. On the other hand, the Soil and water assessment 
Tool may be capable to simulate a individual watershed or a system of more than one hydrologically joined watersheds, each of which separated into sub basins. The sub basin created should finally partition to hydrologic response units (HRUs) depending on soil classifications and land use distributions. Although Didessa sub basin is less studied sub basin of Upper Blue Nile, there have been several successful SWAT simulations at other sub basins of Blue Nile, Ethiopia. As a further contribution to SWAT simulations in Ethiopia, on this study the Soil and Water Assessment Tool model is established to a sub basin of Upper Blue Nile Basin, namely Didessa sub basin.

Likewise anthropogenic activities are dramatically expanding in Ethiopia owed to population growth at alarming rate as well as investment advancement of the country[7 - 9] and model based estimation of watershed outflow is the base in monsoonal climate where, rainfall-runoff relationship of the several landscapes units have complicated hydrology[10]. Generally "watershed variables attributed to the differences in hydrological response of rainfall are soil properties, geology, anthropogenic activities, relief size, local climate and vegetation cover"[10 - 13].

Model based approximation of watershed outflow enlarges the prognostic power of watershed hydrology, as this provides a basis for planning of land management issues for developing and securing water resources [14]. Therefore, understanding the watersheds as sources for stream flow is about significant essentialness in the effective usage of water resources, to enhance management activities of water resources, and to mitigate adverse effects of climate change later on. In line with this critical knowledge gap the flood occurrence in 2015 at Arjo Dedessa dam site initiate this study at this particular watershed.

The stream of Didessa, the biggest branch of Upper Blue Nile (Abay river of Ethiopia) shares approximately about one fourth of the down stream of Blue Nile [15] has entire catchment area drained toward those waterway is assessed to be $28,000 \mathrm{~km}^{2}$. Although the sub basin has comparatively sufficient hydrological and meteorological data series, its hydrological situation have not been well investigated as compared with northern side sub basins of the Blue Nile (Tana sub basin). In relation with its catchment situation, the occurrence of the 2015 flood incidence at the coffer dam site with below normal rainfall season, calling an urgent discussion and evaluation of the hydrological design of the coffer dam and the relief culvert (OWWDSE, 2016). It further invites detail hydrological study to understand and differentiate dominant hydrological processes and parameters, which govern the hydrological condition of the sub basin.

Therefore, this study is relevant to fill the knowledge gap of the hydrological situation of the sub basin with finding scientific cause for the flood occurrence and to make sustainable the water resources development activity in the sub basin. The foremost objective of the study is to understand the hydrological situation of Didesa Sub basin that possible elaborated with the following specific objectives: to (1) find the sensitive parameters for the sub basin by using SWAT-CUP algorithm (Sufi2), (2) evaluate the best probabilty distributions of flow data using EasyFit, (3) identify the sub catchment which contribute the highest flow, (4) Evaluate the water balance of the main sub catchments of the sub basin using SWAT simulated flow and (5) undertake frequency analysis of to fix extreme Floods with different return periods.

\section{Materials and Methods}

\subsection{Study Area}

Didessa sub-basin is located in western part of Ethiopia between latitude $07^{0} 40^{\prime}-10^{\circ} 0^{\prime}$ North and longitude $35^{\circ} 32^{\prime}-37^{0} 15^{\prime}$ East. The overall elevation in the basin varies between 653 and 3144 meter above sea level. The absolute catchment coverage drained by the river is projected and delineated to be $28,229 \mathrm{~km}^{2}$ initiating from the mount of Gomma in South Western Ethiopia. The SWAT simulated average yearly precipitation of the study area is found to be $1745 \mathrm{~mm}$. Most of Didessa sub basin is found in humid tropical climate with heavy rainfall and most of the 
94

95

96

97

98

99

100

101

102

103

104

105

annual preccipitation is recieved during one season named kiremt. The highest and lowest temperature ranges amidst $21.3-30.90 \mathrm{C}$ and $10.9-15.10 \mathrm{C}$, respectively.

From the assessment of land use/cover, major land use types identified include moderately cultivated, dense woodland, intensively cultivated land, wooded grassland, open woodland, natural forest cover, natural forest with coffee, coffee farm with shade trees, riverine forest, bamboo forest, plantation forest, settlement, shrub land and open grassland. According to Oromia Water Work Design and supervision (OWWDSE) [47] of Arjo Didessa dam project feasibility study of 2014 different land use types in different land cover have been identified in the sub basin. These include mixed cultivation, coffee production, livestock production, subsistence and commercial forest products utilization, non-timber products utilization, beekeeping, Wildlife management and utilization, infrastructure development, mining and investment activities on different activities

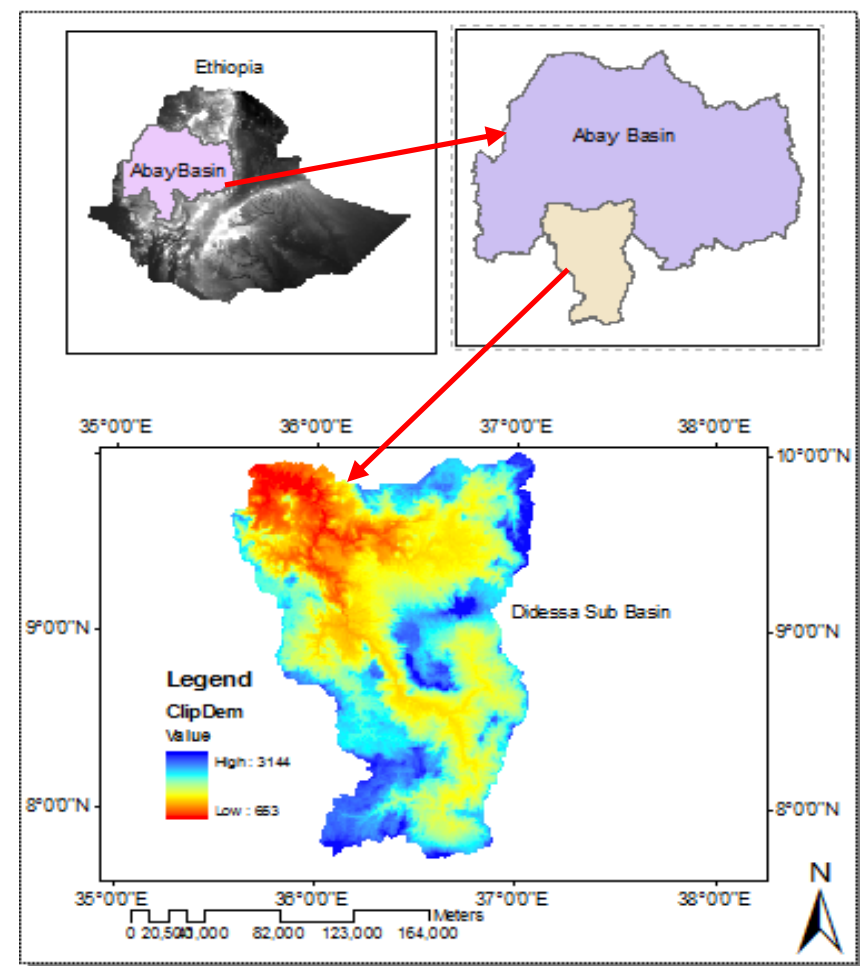

Figure 1. Didessa Sub-basin study site, Abay basin, Ethiopia

\subsection{Input Dataset and Sources of Data for the model}

Swat requires daily weather data including precipitation, wind Speed, minimum and maximum temperature, relative humidity and solar radiation. The main data categories that were utilized in this study incorporate climate, hydrology, soils, land use/land cover information and more advanced DEM of 30mx30m spatial resolution. Weather or Climate information was gathered from National Meteorological Agency of Ethiopia whereas daily flow records were obtained from Ministry of Water, Irrigation and Energy of Ethiopia. Furthermore, landuse/cover ((MERIS land use land cover, 2009) were gotten from Oromia Water work Design and Supervision Enterprise (OWWDSE)[47]. Lastly, Soil shape file was collected from Dr. Belete Berhanu,Soil geo-database of Ethiopia' prepared by [16].The meteorological stations are scatter populated and some stations base period are recent with high missing record. In the case of unavailability of relative humidity, wind speed, and sun shine hour's data the model might have been run with daily rainfall and temperature. Underneath table 1 
120 indicates recorded weather monitoring stations plus accessible information of the time range utilized

121 as input of the study area.

122 Flow records obtained from the Ministry of Water and Energy in Ethiopia at relevant gauging

123 station of Didessa river basin is located near Dembi (Toba),Arjo Didesa near Arjo,Dabana near

124 Abasina,Wama near Nekemte and Angar near Nekemte.

125

126 Table 1. List of Selected weather monitoring Stations and Available data sets for rainfall and climatic variables

\begin{tabular}{llllllll}
\hline $\begin{array}{l}\text { Station } \\
\text { Name }\end{array}$ & Zone & $\begin{array}{l}\text { Station } \\
\text { Elevation(m) }\end{array}$ & $\begin{array}{l}\text { Latitude } \\
(\mathbf{D e g})\end{array}$ & $\begin{array}{l}\text { Longitude } \\
\mathbf{( D e g )}\end{array}$ & $\begin{array}{l}\text { Data } \\
\text { coverage } \\
\text { (year) }\end{array}$ & $\begin{array}{l}\text { \% of } \\
\text { missing } \\
\text { Rainfall }\end{array}$ & $\begin{array}{l}\text { \% of } \\
\text { missing } \\
\text { Temp. }\end{array}$ \\
\hline Bedele & Illubabor & 2011 & 8.5 & 36.3 & $1980-2015$ & 17 & 24.9 \\
Arjo & Misrak Wellega & 2565 & 8.8 & 36.5 & $1989-2015$ & 27 & 33.1 \\
Shambu & Misrak Wellega & 2460 & 9.6 & 37.1 & $1980-2015$ & 14 & 41.0 \\
Nekemte & Misrak Wellega & 2080 & 9.1 & 36.5 & $1980-2014$ & 7 & 11.5 \\
Gimbi & Mirab Wellega & 1970 & 9.2 & 35.8 & $1980-2015$ & 18 & 41.4 \\
Nedjo & Mirab Wellega & 1800 & 9.5 & 35.5 & $1980-2015$ & 20 & 21.8 \\
Jimma & Jimma & 1718 & 7.7 & 36.8 & $1980-2015$ & 5 & 4.6 \\
Dedessa & Misrak Wellega & 1310 & 9.4 & 36.1 & $1980-2015$ & 18 & 38.1 \\
\hline
\end{tabular}

\section{7}

128 Table 2. Basic Hydrometric monitoring description for Didesa River Basin

\begin{tabular}{lllllllllll}
\hline & River & Station & \multicolumn{2}{c}{ Latitude } & \multicolumn{2}{c}{ Longitude } & Catchment & Data coverage & \% Missing \\
S.N & & & Deg. & Min & Deg. & min & area $\left(\mathbf{k m}^{2}\right)$ & (year) & \\
\hline 1 & Didessa & Arjo & 8 & 41 & 36 & 25 & 9,981 & $1980-2014$ & 6 \\
2 & Anger & Nekemte & 9 & 26 & 36 & 31 & 4,674 & $1995-2004$ & 7 \\
3 & Dabana & Abasina & 9 & 02 & 36 & 03 & 2,881 & $1980-1985$ & 12 \\
4 & Didesa & Nr. Dembi & 9 & 30 & 36 & 35 & 1806 & $1985-2014$ & 7 \\
5 & Wama & Nr. Nekemte & 8 & 47 & 36 & 47 & 844 & $1980-1985$ & 39 \\
\hline
\end{tabular}

129 Land use is amongst the primary facctors influencing loss of soil from surface; likewise 130 evapotranspiration in the catchment. The land use being utilized in this study was that of MERIS

131 (Medium Determination Imaging Spectrometer) based Glob-Cover of 2009. land use map after

132 clipping it to study area and changed to relate for those swat predefined land use grouping. It holds

133 a raster version of the Glob-Cover map with spatial resolution of $30 \mathrm{~m} \times 30 \mathrm{~m}$. Dominate land use or

134 cover for this manuscript was mosaic vegetation or crop lands followed by closed to open shrub land.

135 
137

138

139

140

141

142

143

144

145

146

147

148

Simulation of SWAT necessitates soil composition of different properties like soil textural property, physical and chemical properties. The soil map utilized in this study was gotten from two sources. Firstly, the soil data base acquired from Ministry of Water Resource Irrigation and Energy of Ethiopian has shortage of several soil properties like (available moisture capacity, density, saturated hydraulic conductivity, percentage of sand, silt and clay) compulsory required in the model set up were not available in its data base. Secondly, due to the above data base was deficient in necessary information additional data were substantiated from another source like 'soil geodatabase of Ethiopia' prepared by[11] with spatial resolution of $30 \mathrm{mx} 30 \mathrm{~m}$. The soil data base of Ethiopia which was prepared by Belete Berhanu, contains all the information required for SWAT simulation. In addition, comparison of this soil database of the Ethiopia with the previously available FAO soil database $(F A O, 1998)$ indicates that the soil database from the former has more detail classification than the FAO soil data base.

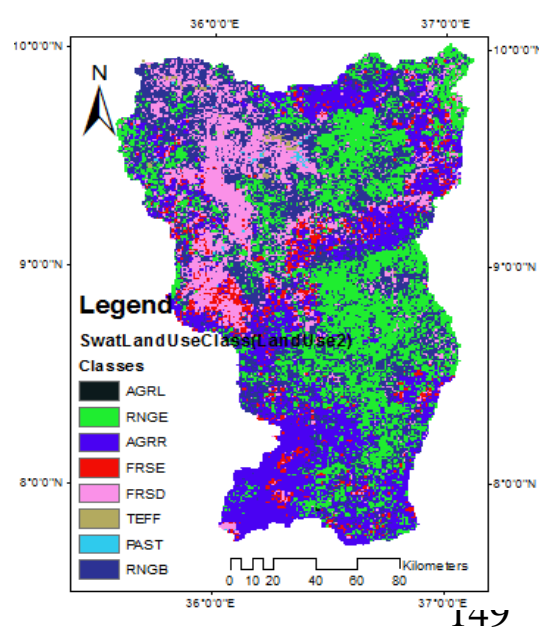

150

\subsection{Testing of dataset quality}

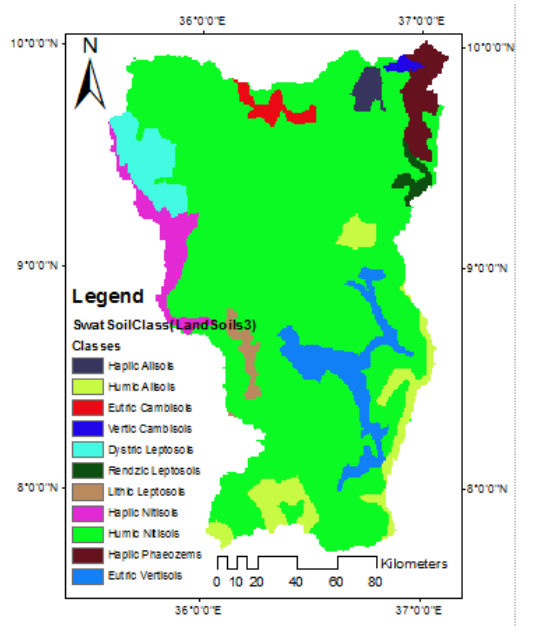

(b)

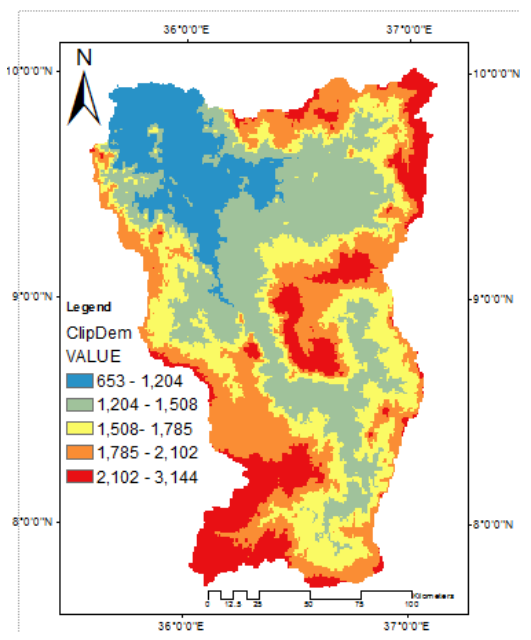

(c)

Figure 2. Physiographic data: (a) Didessa sub basin land cover; (b) soil type; (c) DEM

\subsection{Filling Missing Rainfall and temperature Data}

Before using climate data for the SWAT software, filling of missed data were handled.XLSTAT software is used as filling of missing temperature and rainfall data. XLSTAT started in 1995 to make accessible to anybody a powerful, complete and convenient figures analysis and statistical result. The XLSTAT is easily available and compatible with all the Microsoft Excel versions that are acclimated these days, beginning from Excel 97 to Excel 2016, from the interface in numerous languages and downloaded from the XLSTAT website www.xlstat.com. Some of the application of XLSTAT includes operations like: completing of missing data using advanced missing value treatment techniques either take out observations with absent value, mean imputation method, nearest neighbor approach, NIPALS algorithm, MCMC multiple imputation algorithm. In this paper missing data is treated with "nearest neighbor approach" because the output of this method gives a hopeful result as the output treated value are also checked with those were filled with regression method.

Sometimes a significant change may occur in and around a particular rain gauge stations. Such change occurring in a particular year will start affecting the rain gauge data, being reported from a 
167

168

169

170

171

172

173

174

175

176

177

178

179

180

181

182

183

184

185

186

187

188

189

190

particular station. In order to detect such inconsistency and to correct and adjust the reported rainfall values, a technique called double mass curve method is generally adopted in this study. In this method a group of 8 adjoining stations are selected in the vicinity of suspicious station. The mean daily rainfall values are serially arranged in reverse chronological order to fix relative consistency. The observations from a certain station were compared with the mean of observations from numerous adjacent stations. In accepted double-mass computations, this testing involves removing from the arrangement the records from an uncertain station and comparing them with the remaining data. Since all the dataset were reliable with the accepted totalities in the area, they are re-combined into the base period station. After the data of each station are arranged in descending order, the accumulative sums, station to be investigated and base station; are plotted against each other and line of best fit were sketched in excel assignment sheet.

Seasonal Mann-Kendall Test is adapted to evaluate with a nonparametric test if a trend can be recognized in a series, even when seasonal factor in the sequence. A nonparametric trend test has been primarily suggested via [26] then advanced through [24] finally get enhanced by way of [25] who accustomed to take into account seasonality as well.

The null hypothesis $\mathrm{H} 0$ for these tests implies absence of trend in the series. The next three hypotheses indicate presence of non-null, negative, or positive trend. This test depends on values $\mathrm{P}$ value and Kendall's tau. Kendall's tau shows degree of relationship between two samples. P-value measures whether the null hypothesis was accepted or rejected. If the p-value falls below significance level the alternative hypotheses will be accepted and vice versa. If the time series does have a trend, the data cannot be used for frequency analyses or modelling. Those time series with trend cannot incorporate into hydrological or frequency analysis during modeling for hydraulic structures designs.

\subsection{Selection of parameters for Sensitivity Analysis}

Before calibration to begin, Parameters those were used in SWAT model to other Upper Blue Nile sub basins were identified from previously published muniscript. Since this not enough to get performance criteria, other parameters were gathered and added from SWAT-CUP manual. About nineteen parameters (CN2, ESCO, SOL_AWC, GW_DELAY, GW_REVAP, REVAPMN, GWQMN, ALPHA_BF, RCHRG_DP, CH_K2, SURLAG, CH_N2, and SOL_K, CH_K2, ALPHA_BNK, SLSUBBSN, OV_N, LAT_TIME, ESCO, EPCO, and HRU_SLP) were incorporated into SWAT-CUP aligorithm (Sufi-2) to understand the level their sensitivity. Those parameters along with their sensitivity level were described in (table 6). For the reason that knowing of the more sensitive parameters could make ease the time required for calibration and validation. Furthermore, it is the technique to know the dominant parameters of the watershed those can influence the hydrological balance of the sub basin. The global sensitivity were determined depend on P-value. The smaller the p-value indicates the more sensitive parameter, whereas the larger the p-value point toward the less sensitive for the given watershed[49]. The values close to zero has more significance. According to [30], also sensitivity analysis significantly eases relative sensitivity of parameters identification, rises the accurateness of calibration and lessen uncertainty and the time necessary for it.

\subsection{Data Processing and Model setup}

Data processing in this case includes trend test and homogeneity tests for precipitation data of 8 stations in Didesa sub basin from 1980 to 2014. Moreover, flow data of the sub basin is also tested 
209 for Arjo gauging station from year 1980 to 2014, Dembi station from 1985 to 2014, Angar stations from 2101995 to 2004, for Dabana stations from 1982 to 1985 depending availability of flow data. The seasonal 211 Kendall's tau and p-values for each station is evaluated with XLSTAT software. As p-values are 212 greater than significance level (alpha), the null hypothesis accepted which shows that the data of all 213 the stations are free of trend (table 3).

214 Table 3. Seasonal Mann-Kendall Test for monthly rainfall of Weather gauging stations

\begin{tabular}{|c|c|c|c|}
\hline Station name & Kendall's tau & $\begin{array}{l}\text { p-value(Two- } \\
\text { tailed) }\end{array}$ & alpha \\
\hline JIMMA & 0.041 & 0.281 & 0.05 \\
\hline BEDELE & -0.02 & 0.93 & 0.05 \\
\hline NEKEMTE & -0.00138 & 0.986 & 0.05 \\
\hline DIDESA & -0.0470 & 0.228 & 0.05 \\
\hline GIMBI & 0.0451 & 0.216 & 0.05 \\
\hline NEJO & 0.038 & 0.268 & 0.05 \\
\hline ARJO & 0.0143 & 0.694 & 0.05 \\
\hline SHAMBU & 0.057 & 0.126 & 0.05 \\
\hline
\end{tabular}

215 Note: p-values are greater than significance level (alpha) i.e. 5\%; hence data of all stations are consistent

Alexanderson's SNHT (Standard Normal Homogeneity Test) test for Homogeneity is applied for testing of monthly rainfall. This test i.e. SNHT was established through [48] in order to sense an 218 alternation in a sequences of precipitation data. The test was recommended to series of ratio of 219 observations to compare with average of ratio of several stations. After processing of data the output 220 result shows that the series of precipitation data were remain homogenous. The same procedure was 221 followed to trend test, in trend test interface of XLSTAT and it is found that data are free of trend (see 222 table 4 and figure 3$)$.

Table 4. Alexanderson's SNHT test output value for Homogeneity of rainfall data

\begin{tabular}{|c|c|c|c|}
\hline Station Name & Kendall's tau $\left(\tau_{\mathrm{o}}\right)$ & $\begin{array}{c}\text { p-value } \\
\text { (Two-tailed) }\end{array}$ & alpha \\
\hline JIMMA & 7.7 & 0.146 & 0.05 \\
\hline BEDELE & 2.5 & 0.93 & 0.05 \\
\hline NEKEMTE & 4.8 & 0.5 & 0.05 \\
\hline DIDESA & 3.6 & 0.72 & 0.05 \\
\hline GIMBI & 3.3 & 0.8 & 0.05 \\
\hline NEJO & 2.81 & 0.89 & 0.05 \\
\hline ARJO & 2.2 & 0.96 & 0.05 \\
\hline SHAMBU & 4.1 & 0.63 & 0.05 \\
\hline
\end{tabular}

As shown in table all stations p-values are greater than alpha $(5 \%)$, hence data are homogenous.

Similarly flow series were tested at different gauging stations of Didessa sub basin such as 
228

229

230

231

232

233

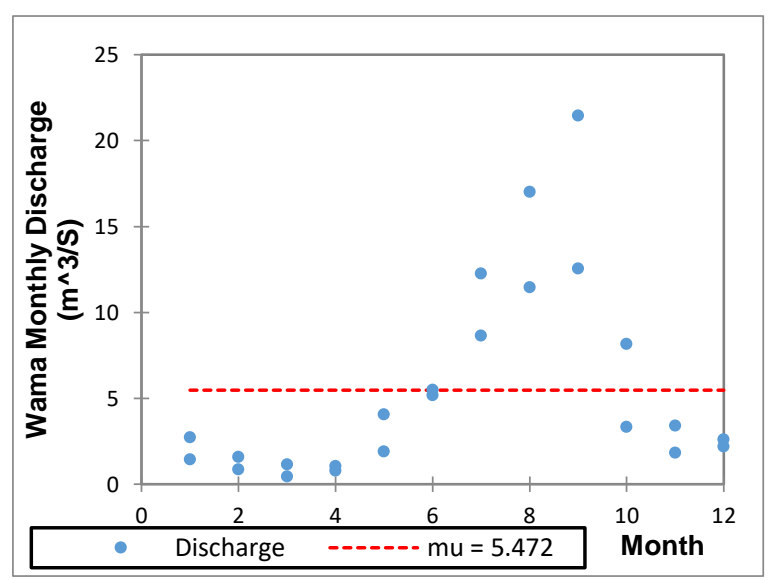

and Angar Near Nekemte (1995-2004). And from trend and homogeneity test it is found that the flow data were homogeneous and no significant trend is found at all discharge gauging stations.
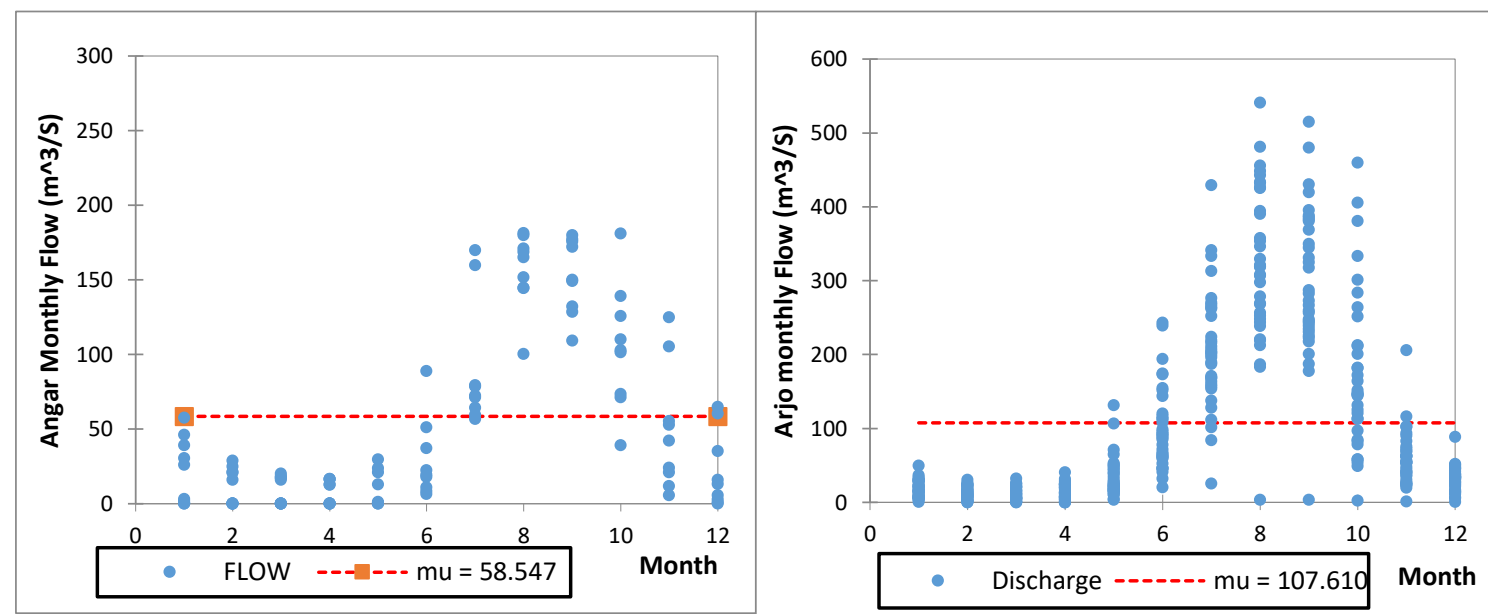

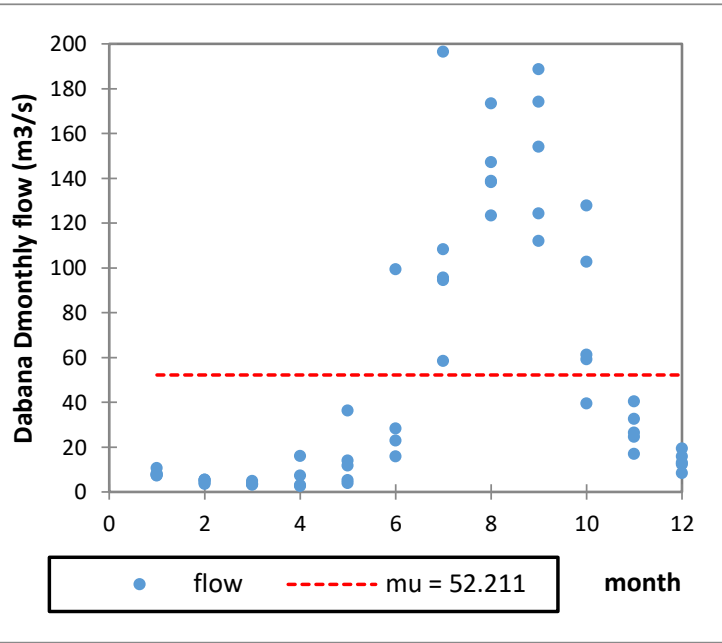

$\mathrm{mu}$ (horizontal red line) indicate the mean of flow data)

Figure3. XLSTAT final output Graphical representation of homogeneity test of Observed Flow data

ArcSWAT version of 2012.10 of ArcGIS 10.1 interface downloaded from website http://swat.tamu.edu/software/arcswat/ is used for watershed delination, HRUs definition and hydrological simulation. DEM of spatial resolution of $30 \mathrm{~m} \times 30 \mathrm{~m}$ was applied in watershed delination. 
240 And land use and soil shape file of the same spatial resolution was used in HRUs definitions.

241 Landuse/soil/slope of thresholds 20/20/20 (\%) respectively,produces 604 HRUs and 112 subbains.

242 Recorded wheather input of daily rainfall and maximum and minimum temperature of 35 years used

243 as input file to produce the simulation. And three years warm up period is took place to activate the

244 Swat run step. Finally, the sequencial Uncertainity Fitting i.e SUFI-2 built in SWAT-CUP aligorithm

245 was used to calibrate and validate the model. SWAT-CUP provides algorithms for auto-calibration,

246 from which Sequential Uncertainty Fitting,Version 2 (SUFI-2) was chosen. SUFI-2 accounts for several

247 sources of uncertainties such as uncertainty in driving variables e.g. rainfall, conceptual model,

248 parameters and measured data [49]. It is not a fully automated calibration tool, since it still requires

249 interaction of the modeller and knowledge about the parameters and their effects on the output [49].

250 In sufi-2 parameters are given ranges as found in Absolute_swat_values before performing iteration.

251 Finally, the aligorithm provides the best estimation and optimum parameters range.

252 Model performances were evaluated graphically and statistical procedures with that of quality

253 criteria. The statistical parameters employed in measure of model quality are Root Mean square

254 (RMS), coefficient of determination ( $\mathrm{R}^{2}$ ), Nash Coefficient (NSE)[37] and PBIAS measure the model

255 quantitatively. In this manuscript model performance was evaluated with values of $\mathrm{R}^{2}$, NSE and

256 PBISAS. The $\mathrm{R}^{2}$ provides for those extents of the discrepancy between observed and simulated with

257 linear association using linear regression model. Coefficient of determination values found between

258 zero and one, which the smaller figure demonstrating more error variation. The figure value more

259 than 0.5 found in satisfactory range for coefficient of determination $[42,43]$ and NSE as well. The

260 Nash Sutcliffe defines the extents of variation between simulated to observed data discrepancy [38].

261 The Nash value situated between this interval $(-\infty, 1]$ and the value close to zero shows as the model

262 performance is more suitable [38,39]. PBIAS is taken as a clear quantifier for water balance

263 errors[40,41] and value close to zero shows the more the value approaches to the acceptable range,

264 positive number explains under estimation of model and negative illustrates model over estimation.

265 Model was desired to evaluated based quality criteria as it can give water balance error which can

266 show that poor model performance[40,41]. For stream flow, the performance rating which ranges

267 between $0.75<$ NSE $<1.00$ and PBIAS $< \pm 10$ is considered as very good for monthly time scale.The

268 model performance is supposed as good for values ranges between $0.65<\mathrm{NSE}<0.75$ and $\pm 10<$ PBIAS

$269< \pm 15$. Values of NSE $<0.50$ and PBIAS $> \pm 25$ demonstrates unsatisfactary ranges of performance. The

270 model performance was considered as satisfactory for an interval value ranges between $0.50<$ NSE

$271<0.65$ and $\pm 15<$ PBIAS $< \pm 25[40]$

272 The $\mathrm{R}^{2}$, NSE and PBIAS were evaluated with the equations (1) up to (3) as follows:

273

$$
\begin{gathered}
\mathrm{NSE}=1-\frac{\sum_{\mathrm{i}=1}^{\mathrm{n}}\left(\mathrm{Qi}^{\mathrm{o}}-\mathrm{Qi}^{\mathrm{s}}\right)^{2}}{\sum_{\mathrm{i}=1}^{\mathrm{n}}\left(\mathrm{Qi}^{\mathrm{m}}-\overline{\mathrm{Q}^{\mathrm{m}}}\right)^{2}}, \\
R^{2}=\frac{\left[\sum_{i=1}^{n}\left(Q_{o . i}-\overline{Q_{o}}\right)\left(Q_{s, i}-\overline{Q_{s}}\right)\right]^{2}}{\sum_{i=1}^{n}\left(Q_{o, i}-\overline{Q_{m o}}\right)^{2}\left(Q_{s, i}-\overline{Q_{s}}\right)^{2}}, \\
P B I A S=100 * \frac{\sum_{i=1}^{n}\left(Q_{o}-Q_{s}\right) i}{\sum_{i=1}^{n} Q_{o, i}},
\end{gathered}
$$


Where, $Q i^{o}$ and $Q i^{s}$ represent measured and Simulated flow at time step i, correspondingly, $\overline{Q^{\circ}}$ and $\overline{Q_{S}}$ are average of measured flow, $n$ indicate grand number of paired measured and observed discharge, $o$ and $S$ are mean measured and simulated discharge, consecutively.

\section{Results}

\subsection{Model Calibration and validation}

Sensitive parameters identification for the sub basin is alternatively required before starting with calibration as well as validation of SWAT to simplify the time consumed in the project work. This procedure involves the determination of sensitive parameters depending on professional or skilled decision[27]. It was vital to identify crucial parameters those needed for the next task i.e. calibration. Maximum of the previously published Soil and water Assessment Tool scholarships involves respective activities of calibration and validation [27] whereas others do calibration without validation due to scarcity of measured data. For this study, flow gauging stations like: Dabana near Abasina and Wama near Nekemte left only with calibration as limited observed discharge of less than 5 years are available after 1980 (starting year of SWAT model run).

Initially, calibration was started on monthly base to recognize size of parameters, as well as seasonal characteristics of flow. After running of SWAT model on monthly time step hydrological water balance is observed and base flow is overestimated. Through calibration in which the values parameters range repeatedly changed during this activity the best promising statistical performance indicator value were attained. Then the daily calibration is succeeded to get more perfect parameter values about watershed as well as to properly estimate annual flow volumes at necessary point or junction as shown in figure 4.

Parameter values are adjusted to fit observed and simulated hydrograph. To decrease model overestimated estimated Base flow, the parameters such as (GW_DEEP), (GWQMN), (GW_REVAP), (REVAPMN) were getting increase to give best correlation between measured and simulated discharge.
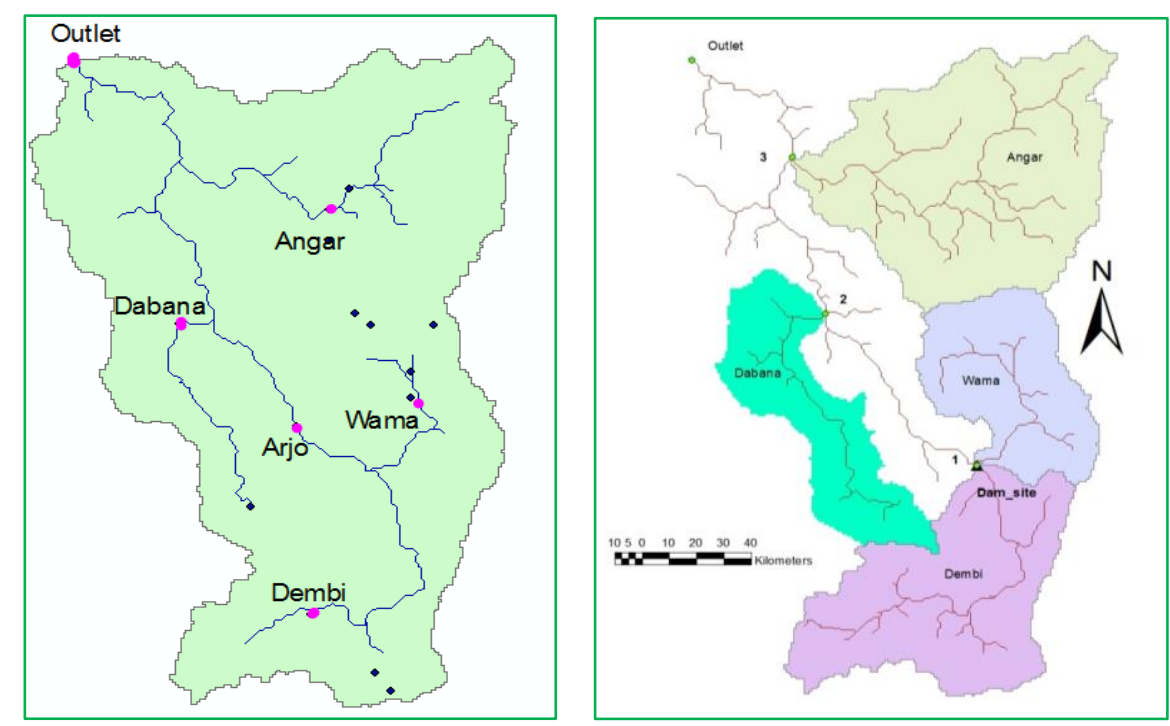

(a)

(b)

Figure 4. (a)location of flow-gauging stations, and (b) Junction(1,2,3) at which hydrograph is simulated 
Model calibration and validation is done depending on location of gauging stations as well as presence of available gauged discharge data. For Dembi and Arjo daily flow data of 18 consecutive years with negligible missing is used for calibration and validation. Angar near Nekemte has 10 years available data within the range of SWAT run period where as Lower Dabana and Wama have 5 years and 4 years data within the range respectively. Hence due to absence sufficient data calibration is done without validation at Dabana and Wama discharge gauging stations. Even though model performance values are not shown in table 5 for these two gauging stations model is calibrated using observed flow. The calibration statistical value is found in the same table. Didessa near Arjo gauging station data are classified in to two depending on hydrological change during 2005 in Didessa sub basin. This change may be due to settlers of Hararghe population, land clearing for sugar cane production and etc. Flow data from 1997 to 2004 and from 2007 to 2014 are used for this watershed to understand the basin characteristics within the two range.

Table 5. Model performance statistics for the Didessa Sub basin at 5 discharge gauging stations.

\begin{tabular}{|c|c|c|c|c|c|}
\hline \multirow{2}{*}{ Time base } & Calibration & (1997-2008) & (1997-2001) & (2006-2011) & (1997-2001) \\
\hline & Criterion & Dembi & Arjo & Arjo & Angar \\
\hline \multirow{7}{*}{ Daily } & $\mathrm{R}^{2}$ & 0.66 & 0.74 & 74 & 0.8 \\
\hline & NSE & 0.6 & 0.74 & 0.65 & 0.8 \\
\hline & PBIAS & -10.5 & -6.1 & -19.4 & 0.5 \\
\hline & Validation & (2009-2014) & (2002-2004) & (2012-2014) & (2002-2004) \\
\hline & $\mathrm{R}^{2}$ & 0.70 & 0.70 & 0.64 & 0.62 \\
\hline & NSE & 0.66 & 0.62 & 0.6 & 0.61 \\
\hline & PBIAS & -6 & 0.0 & -4 & -16.3 \\
\hline \multirow{8}{*}{ Monthly } & Calibration & (1997-2008) & (1997-2001) & (2006-2011) & (1997-2001) \\
\hline & $\mathrm{R}^{2}$ & 0.80 & 0.87 & 0.75 & 0.82 \\
\hline & NSE & 0.72 & 0.82 & 0.71 & 0.79 \\
\hline & PBIAS & -16.4 & -10.5 & 2.5 & -3.5 \\
\hline & Validation & (2009-2014) & $(2002-2004)$ & (2012-2014) & (2002-2004) \\
\hline & $\mathrm{R}^{2}$ & 0.86 & 0.89 & 0.82 & 0.92 \\
\hline & NSE & 0.83 & 0.84 & 0.81 & 0.91 \\
\hline & PBIAS & -13.3 & -20 & 7.7 & -13.4 \\
\hline
\end{tabular}

In both calibration and validation this model shows acceptable statistical values of performance measurements on the Didessa sub basin at all the gauging stations. It produced acceptable results in terms of NSE, PBIAS and $\mathrm{R}^{2}$ whether on daily or monthly time steps. In both daily and monthly, model calibration and validation returned a NSE $\geq 0.6$ which shows that the figure is acceptable. In most stations daily performance are greater than that of monthly in terms of PBIAS. Specifically, in some of the stations very good values of NSE and $R^{2}$ were obtained and were $>0.75$ on monthly time scale. Likewise, it might be recognized that the model performance is slightly low on daily time step than monthly as it was indicated in table 5. Only one station i.e. Arjo showed low performance in the case of percent of biased (PBIAS) of -20 even though NS and $\mathrm{R}^{2}$ are very good at monthly time basis. So as daily calibration and validation demonstrates lower percent of biased, for water balance and flow hydrograph simulation and prediction daily was used. The calibrated and validated result shows shat, for all stations; higher percent of biased was found in daily time base. Furthermore, since average of data is simulated on monthly time step, it is not good as daily time step in water balance prediction at necessary junction to estimate flow for design purpose. The SWAT parameters used in in calibration, its optimum value and variation methods are indicated in table 6 below. For all the watersheds flow is well reproduced for both wet and dry season. The graphical representation 
336

337

338

339

340

341

342

of Calibration and validation done in sufi- 2 of SWAT-CUP algorithm shows that the peak and dry season flows were well developed as indicated in figure 5 and figure 6 below on monthly time scale and daily time scale respectively.

Table 6 Parameters used in ncalibration of SWAT model and its optimum values

\begin{tabular}{|c|c|c|c|c|c|c|c|c|}
\hline \multirow[t]{2}{*}{ Parameters } & \multicolumn{8}{|c|}{ Fitted Values } \\
\hline & Range & Dembi & $\begin{array}{l}\text { Arjo(19 } \\
\text { 97-2004) }\end{array}$ & $\begin{array}{l}\text { Arjo(2006- } \\
\text { 2014) }\end{array}$ & Angar & Dabana & $\begin{array}{l}\text { Wam } \\
\text { a }\end{array}$ & $\begin{array}{l}\text { Variation } \\
\text { Methods }\end{array}$ \\
\hline V_ALPHA_BF & $0-1$ & 0.45 & 0.357 & 0.511 & 0.721 & 0.741 & 0.545 & Replacement \\
\hline V_ALPHA_BNK & $-0.1-1$ & -0.01 & 0.745 & 0.327 & 0.457 & 0.175 & 0.755 & Replacement \\
\hline V_CH_K2 & $0-500$ & 125.68 & 488.78 & 309.204 & 285.0 & 451.31 & 486.2 & Replacement \\
\hline V_CH_N2 & $-0.01-0.3$ & 0.273 & 0.191 & 0.056 & 0.389 & 0.276 & 0.213 & Replacement \\
\hline R_CN2 & $-0.25-0.25$ & 0.11 & 0.124 & 0.15 & 0.107 & 0.153 & 0.1 & Relative \\
\hline V_EPCO & $0-0.9$ & 0.062 & 0.529 & 0.213 & 0.042 & 0.11 & 0.103 & Replacement \\
\hline V_ESCO & $0-0.1$ & 0.002 & 0.001 & 0.003 & 0.0022 & 0.0023 & 0.0021 & Replacement \\
\hline V_GW_DELAY & $0-0.3$ & 0.01 & 0.604 & 0.234 & -0.001 & 0.01 & 0.005 & Replacement \\
\hline V_GW_REVAP & $0-0.2$ & 0.199 & 0.183 & 0.17 & 0.181 & 0.177 & 0.179 & Replacement \\
\hline V_GWQMN & $0-5000$ & 3044.4 & 4850 & 4616.7 & 1683.2 & 3705.5 & 4596.8 & Replacement \\
\hline R_HRU_SLP & $-1-0.4$ & -0.871 & 0.784 & -0.112 & 0.287 & 0.196 & -0.665 & Relative \\
\hline V_LAT_TTIME & $0-25$ & 5.934 & 12.643 & 28.4 & 4.957 & 5.217 & 1.141 & Replacement \\
\hline V_OV_N & $0-15$ & 6.237 & 7.426 & 5.776 & 1.502 & 1.577 & 6.718 & Replacement \\
\hline V_RCHRG_DP & $0-1$ & 0.258 & 0.222 & 0.124 & 0.422 & 0.265 & 0.832 & Replacement \\
\hline V_REVAPMN & $0-500$ & 147.78 & 299.45 & 125.7 & 149.06 & 303.0 & 485.9 & Replacement \\
\hline V_SLSUBBSN & $0-180$ & 123.12 & 87.891 & 169.2 & 57.057 & 123.0 & 91.9 & Replacement \\
\hline R_SOL_AWC & $-02-0.51$ & -0.049 & -0.101 & 0.025 & 0.356 & 0.052 & 0.077 & Relative \\
\hline R_SOL_K & $-0.1-0.25$ & -0.136 & 0.009 & 0.121 & 0.166 & 0.038 & -0.02 & Relative \\
\hline V_SURLAG & $0-30$ & 16.74 & 20 & 10.4 & 4.711 & 6.258 & 12.5 & Replacement \\
\hline
\end{tabular}

The sensitivity of parameters was computed to simplify the time consumed in model calibration and validation. Identification of sensitivity level of those parameters of the sub basin is also crucial to understand their effect on watershed to produce surface runoff. The ranks of sensitivity, which depends on p-value obtained during iteration in SWAT-CUP algorithm of Sufi-2 were tabulated in (Table A1) for gauging stations involved in this study. The parameter's rank given in the table was obtained during calibration on daily time step. Some of the sensitive parameters are similar to those found by [28] sensitive parameters for Abbay basin. Among nineteen parameters selected for model calibration the $\mathrm{CN}_{2}$ (curve number), (SOL_AWC(available water capacity), HRU_SLP(average slope steepness), (SOL_K)saturated hydraulic conductivity, GW_REVAP(ground water revaporation

354 coefficient),GWQMN (threshold water depth in the shallow aquifer for flow), and ALPHA_BF (base flow alpha factor) were found to be those with higher rank at different outlet. 
356

357

358

359

360
New sensitive parameters those can affect flow are Manning's " $n$ " value for the main channel (CH_N2), LAT_TIME Lateral flow travel time, and OV_N (Manning's roughness coefficient) for overland flow were found. The level of parameter's sensitivity was different at different outlets. Nevertheless the $\mathrm{CN}_{2}$ (curve number) was the main sensitivity parameter for all outlets. 

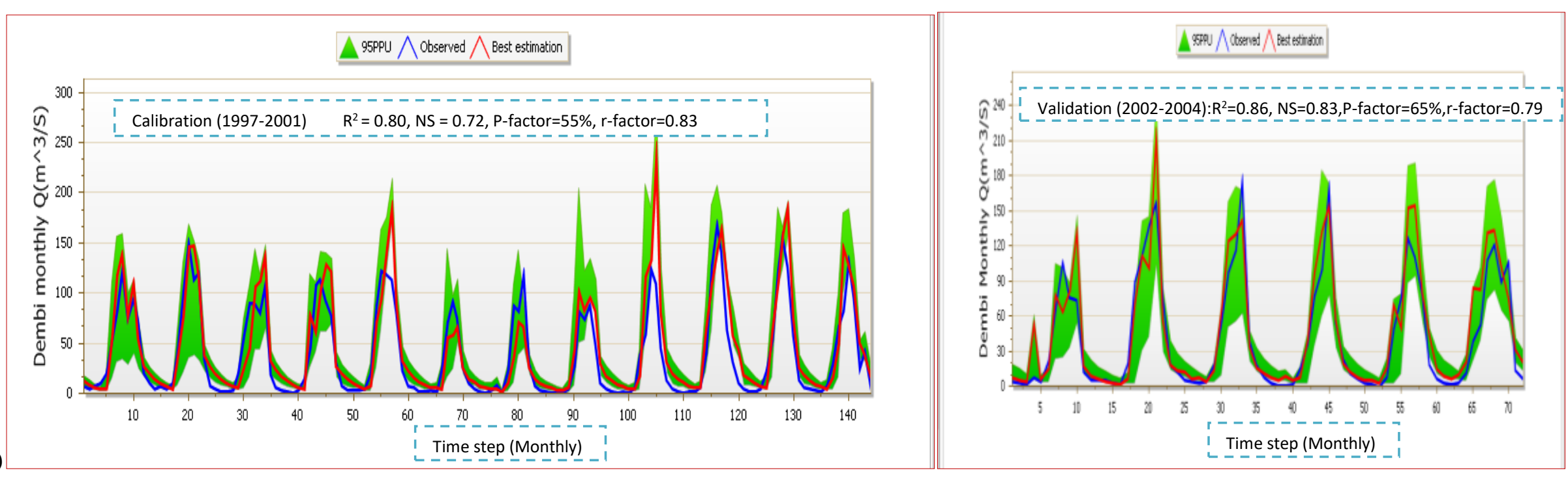

361

(a)
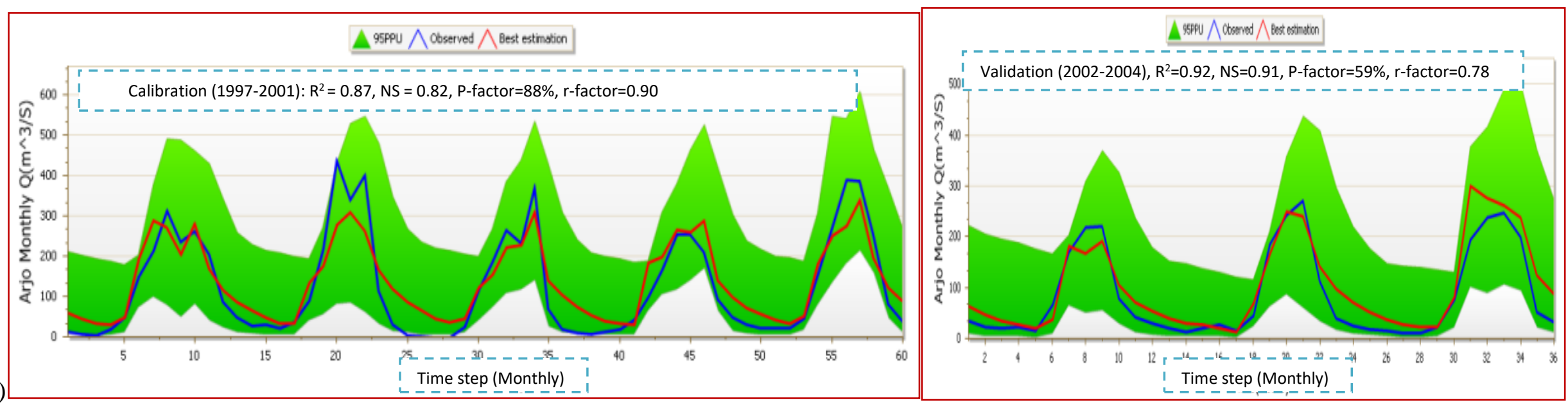

(b) Time step (Monthly) 

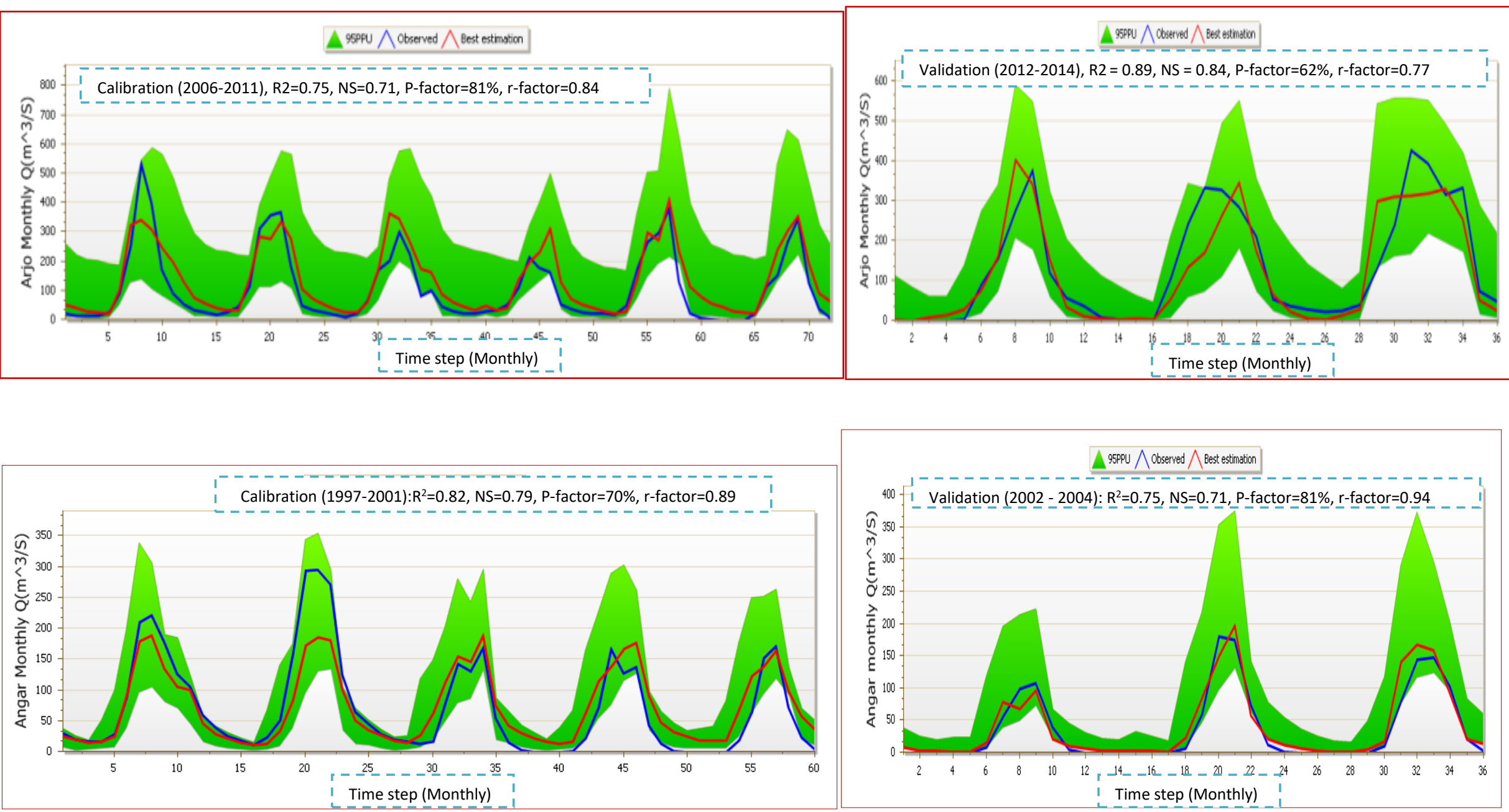

Figure 5. Simulated and observed hydrographs at the 3 flow gauging station (a) Dembi, $(b, c)$ validation and,(d) Angar at monthly time steps. 

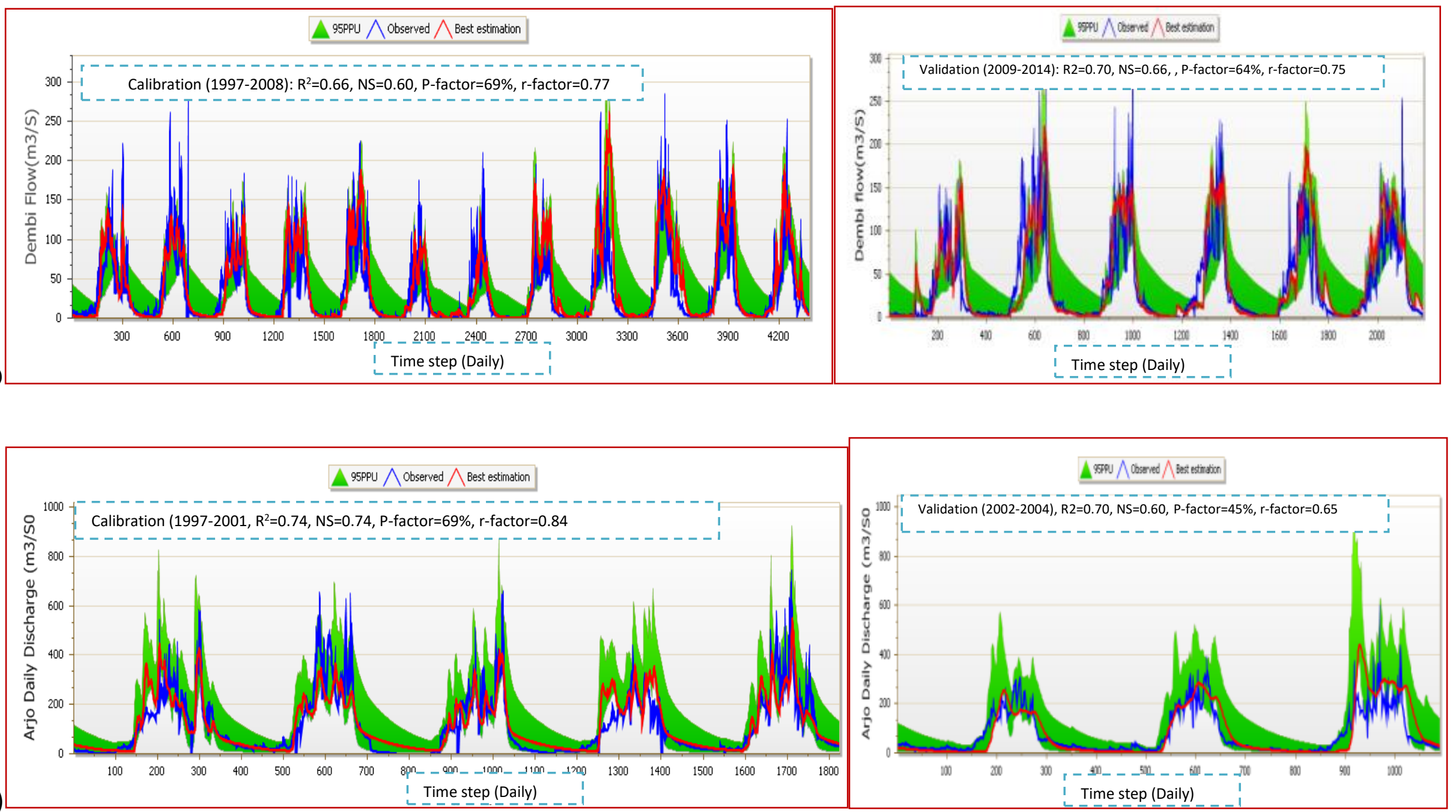

(b) me step (Daily) 

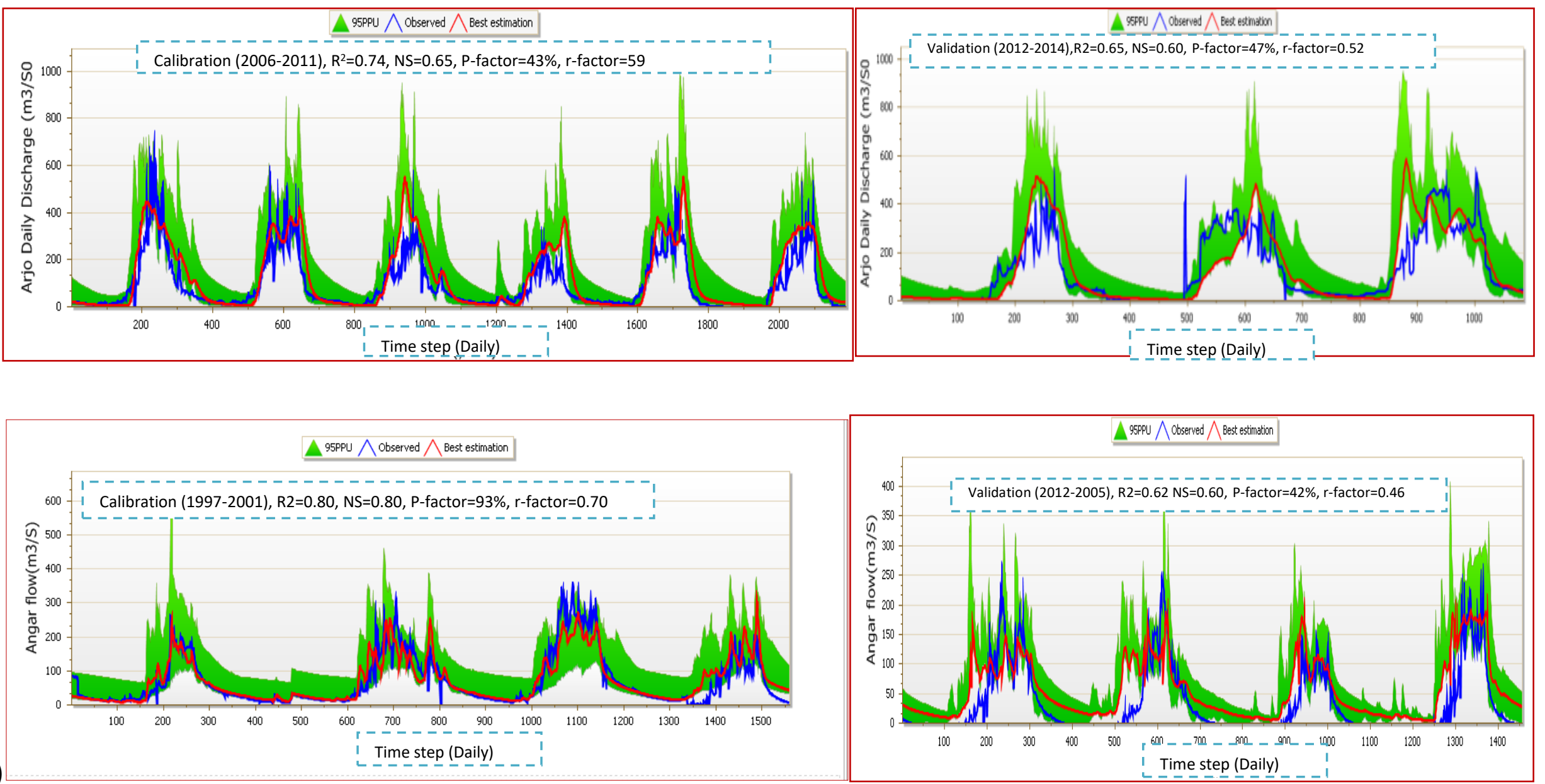

(d)

Figure 6. Simulated and observed hydrographs at the 3 flow gauging station (a) Dembi, $(b, c)$ Arjo,and (d) Angar at daily time steps 
After running of SWAT model hydrological water balance is observed and in fact base flow is of flow by the model. This may be due to the reason that the soil shape file applied in this model set up is single layered soil data. During iteration in in SWAT-CUP aligorithm i.e. Sufi-2 calibration parameters are adjusted to fit observed and simulated hydrograph. Changing of calibration parameters have significant influence on hydrological component. For this reason, in this study to decrease Base flow, increase deep percolation (GW_DEEP), Threshold depth of water in the shallow aquifer required for return flow to occur (GWQMN), increase the groundwater revap-coefficient (GW_REVAP), and increase the threshold depth of water in shallow aquifer (REVAPMN) was done. To correct the late shift, the slope (HRU_SLP) increased, and Manning's roughness coefficient $\left(\mathrm{OV} \_\mathrm{N}\right)$ as well as the value of overland flow rate (SLSUBBSN) decreased. SCS runoff curve number $\left(\mathrm{CN}_{2}\right)$ value is getting increased to increase the value of surface run off. Finally, Deep aquifer percolation fraction (RCHRG_DP) value is also getting larger than that of during Swat run to increase the amount of water percolated to deep aquifer.

\subsection{Water Balance of Didessa Sub Basin}

Water balance analysis of the sub basin is done with a given land use. In addition the calibrated parameters are reinserted during ArcSWAT run for each watershed to get appropriate balance. This sort of evaluation has been required to acquire an Understanding of the whole hydrological response of catchment. At the same time it provides for an essential consideration of the rainfall-runoff association through a long period of time. The outcome of such investigation considers the general breakdown of precipitation and their proportions which defining runoff from sub basin,subsurface and evapotranspiration, and etc. This evaluation involves comparison of input climate data to that of observed stream flow. The breaking of inputs to the output water balance components could aid in deciding those possibility sensitivities of the watershed to change in land use or land cover. The general long term hydrological water balance and hydrological parameters estimated and tabulated in table 7 .

Table 7.Hydrological water balance ratio and hydrological variables

\begin{tabular}{l|cccccc}
\hline Hydrology (water balance ratio) & Dembi & Arjo & Dabana & Wama & Angar & L/Didesa \\
\hline Stream flow/precipitation & 0.21 & 0.2 & 0.28 & 0.15 & 0.20 & 0.22 \\
Base flow/total flow & 0.21 & 0.28 & 0.27 & 0.32 & 0.39 & 0.4 \\
Surface run-off/total flow & 0.79 & 0.72 & 0.73 & 0.68 & 0.61 & 0.60 \\
Percolation/precipitation & 0.28 & 0.34 & 0.29 & 0.36 & 0.35 & 0.30 \\
Deep recharge/precipitation & 0.07 & 0.13 & 0.08 & 0.3 & 0.15 & 0.11 \\
ET/precipitation & 0.55 & 0.51 & 0.50 & 0.48 & 0.52 & 0.52 \\
\hline Hydrological variables (all units in mm) & Dembi & Arjo & Dabana & Wama & Angar & L/Didesa \\
\hline Evap. and transpiration & 964.5 & 951.7 & 932.8 & 961.5 & 860.3 & 960.0 \\
Precipitation & 1740 & 1862.9 & 1861.7 & 1990.2 & 1669.9 & 1850.6 \\
Surface run-off & 287.4 & 264.71 & 376.41 & 209.1 & 204.5 & 245.8 \\
Lateral flow & 3.37 & 5.2 & 13.42 & 98.92 & 17.66 & 91.1 \\
Return flow & 74.9 & 95.24 & 124.6 & 0.0 & 115.14 & 71.9 \\
\hline
\end{tabular}

All Units are in (mm) 


\subsection{Flow of major tributaries}

Average monthly basin rainfall, Evapo-transpiration, surface flow, Potential Evapotranspiration and average basin yield is obtained From ArcSWAT output. From this out put one can understand hydrological situation of the basin in terms of months with high and minimum surface and base flow. To easily understand the hydrological situation of the sub basin, it is better to classify the output into two major categories i.e. wet and dry season which is common in Ethiopia. According to climate of the study area the wet season ranges from May to October where as dry season is when precipitation is almost negligible and for all months between November and April. Peak flow and lowermost flow is developed during the month of August and April respectively.

The study also extended to evaluate the water yield of the major tributaries to identify the catchment which contributes maximum annual flow along with their catchment area. The four major tributaries of Didessa sub basin are: Angar,Dembi or Toba,Wama, and Dabana in their consecutive order of catchment size.

Angar catchment is the largest in case of catchment size $\left(7988.2 \mathrm{Km}^{2}\right)$, receives annual precipitation of $1670 \mathrm{~mm}$ and takes share water yield of about $4.46^{*} 10^{9} \mathrm{~m}^{3}$ to Didessa sub basin and then flows to the Upper Blue Nile River from simulated daily flow.

The fourth rank in terms of catchment size $\left(3246.4 \mathrm{~km}^{2}\right)$, tributary of Didessa sub basin is Dabana catchment. The catchment can receive simulated annual rainfall of $1861.7 \mathrm{~mm}$, and contribute flow of $2.15^{*} 10^{9} \mathrm{~m}^{3}$ annually to the upper Blue Nile of Ethiopia.

The next tributary of Didessa sub basin is called Wama catchment take third rank in terms of catchment size $\left(3336.8 \mathrm{~km}^{2}\right)$. Wama catchment receives an annual rainfall amount of $1990.2 \mathrm{~mm}$ and donates $2.71^{*} 10^{9} \mathrm{~m}^{3}$ of annual flow to the upper Blue Nile of Ethiopia.

The second rank in catchment size $\left(5532.1 \mathrm{~km}^{2}\right)$, and in which the construction of embankment dam is in progress is Dembi tributary. Dembi receives an annual rainfall of about $1740 \mathrm{~mm}$, and contribute $3.1^{*} 10^{9} \mathrm{~m}^{3}$ flow to the upper Blue Nile or Didessa sub basin every year.

Generally, Didessa sub basin contributes about quarter of average flow of Abay basin of Ethiopia. According to simulated output flow volume of about 10.7 Billion meter cube of flow is annually donated to the Upper Blue Nile of Ethiopia from Didessa sub basin. In percentage it shares about $26 \%$ of Abay basin $\left(54.810^{9} \mathrm{~m}^{3}\right)$ which is measured at Sudan border [31].The results are summarized in table 8 .

Table 8. Average yearly water budget of main tributaries

\begin{tabular}{|c|c|c|c|c|c|c|c|c|}
\hline \multirow[t]{2}{*}{ S.No } & \multirow{2}{*}{$\begin{array}{l}\text { Name. of } \\
\text { Tributary/ } \\
\text { Reach }\end{array}$} & \multirow{2}{*}{$\begin{array}{l}\text { Precipit } \\
\text { ation } \\
(\mathrm{mm})\end{array}$} & \multirow{2}{*}{$\begin{array}{l}\text { Mean } \\
\text { annaul } \\
\text { Flow (m3/s) }\end{array}$} & \multirow[t]{2}{*}{$\begin{array}{l}\text { SURQ } \\
(\mathrm{mm})\end{array}$} & \multirow[t]{2}{*}{$\begin{array}{l}\text { PET } \\
(\mathrm{mm})\end{array}$} & \multirow[t]{2}{*}{$\begin{array}{l}\mathrm{ET} \\
(\mathrm{mm})\end{array}$} & \multicolumn{2}{|c|}{$\begin{array}{l}\text { Total Annual } \\
\text { Water Yield }\end{array}$} \\
\hline & & & & & & & $\begin{array}{l}\text { Depth } \\
(\mathrm{mm})\end{array}$ & $\begin{array}{l}\text { Volume } \\
\left(10^{9} \mathrm{~m}^{3)}\right.\end{array}$ \\
\hline 1 & Dembi & 1740 & 84.5 & 287.4 & 1404.1 & 964.1 & 482.6 & 3.1 \\
\hline 2 & Dabana & 1861.7 & 67.6 & 376.4 & 1456.7 & 932.4 & 656.4 & 2.15 \\
\hline 3 & Wama & 1990.2 & 86.1 & 209.1 & 1195.5 & 961.0 & 902.3 & 2.71 \\
\hline 4 & Angar & 1669.9 & 147.2 & 204.4 & 1359.6 & 860.2 & 583 & 4.6 \\
\hline
\end{tabular}


Comparing simulated average monthly flow with Abbay master plan study of 1999, the SWAT model underestimates the monthly flow during peak for Arjo Didesa and Angar gauging station. The small difference may be the model used in estimation of flow and the data range used in Master plan study (1962 to 1992 for Didessa at Arjo, and 1960 to 1992 for Angar at Nekemte) in monthly estimation as it is shown in figure 8.

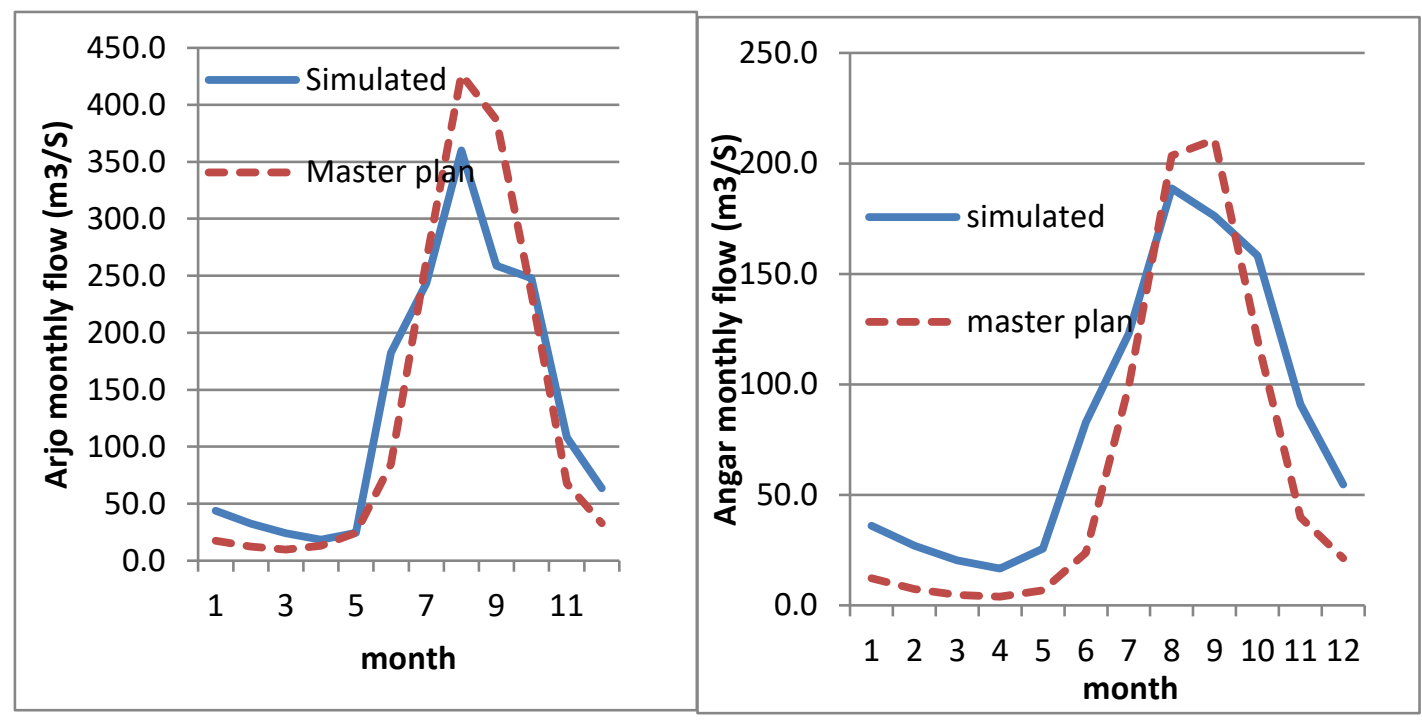

(a)

(b)

Figure 7. Comparaison of simulated vs Abay basin master plan study at gauging stations (a) Arjo Didessa, (b) Angar

\subsection{Frequency Analysis}

The foremost purpose of frequency analysis to know the relationship between extreme flood with their occurrence through statistical procedures[33]. The end result of this analysis is used in design of hydraulic structures; especially, dams, culverts, diversion structures and etc. frequency analysis are evaluated from simulated flow hydrograph of each major tributary, and can be calculated by using the following formula.

$$
x_{T}=\bar{x}+K_{T} * S,
$$

Where, $\bar{x}$ peak flow mean, s=standard deviation of peak flow and, $K_{T}$, magnitude of extreme event at time at return period $\mathrm{T}$.

The frequency distribution parameters and the distribution type were determined in EasyFit software. EasyFit, which is a data analysis and simulation software was used to fit and simulate statistical distributions of flow data, choose the best model, and use the obtained result of analysis to take better decisions. This analysis method is preferred in cases which one has little or no information about base distributions existing in data, and want to find the general type of distribution [53]. The distribution with the highest frequency was chosen as the best distribution for a particular watershed. [52] The purpose of recognizing distributions for data in essence increases the validity of models, which, in turn, leads to better decisions. The statistical parameters determined by Easyfit like mean, standard deviation, skewnes coefficient are tabulated in Table 9.

EasyFit shows that all the watershed fit normal and Lognormal model except Dembi and Wama which $\mathrm{w}$ found to give good fit with Logpearson-3 and pearson-5 respectively. The values of 
458

459

460

461

462

463

464

465

466

467

parameters such as mean $(\mu)$, stndard deviation $(\sigma)$ were calculated for each watershed and the result found in Easy fit test was tabulated in (table 9).

To decide which distribution is suitable for each major tributories, the goodness of fit tests, including Kolmogorov- Smirnov (KS), Anderson-Darling (AD), and Chi-square for all the data sets were done for all the watershed at outlet point with 12 years daily data and parameters distribution parameters are found in table 9. Anderson-Darling test is much more sensitive to the tails of distribution, whereas Kolmogorov-Smirnov test is more aware of the center of distribution. To sum up, Anderson-Darling would recommend to use, to get much more powerful test. The KolmogorovSmirnov and Anderson-Darling tests were limited to continuous distributions.

Table 9.Distribution parameters value for each watershed

\begin{tabular}{lllll}
\hline Test type & Watershed & Distribution type & parameters & Parameters value \\
& Dembi & Logpearson(3P) & $\alpha, \beta$ and $\gamma$ & $1545.9,-0.0388$ and 62.83 \\
Kolmogorov-Smirnov & Dabana & Weibull & $\alpha, \beta$ and $\gamma$ & $0.609,37.51$ and 2.495 \\
& Angar & Normal & $\mu, \sigma$ and $\gamma$ & $52.793,68.0$, and 0 \\
& Wama & Lognormal(3P) & $\mu, \sigma$ and $\gamma$ & $0.96,1.2788$ and 0.2718 \\
& Arjo Didessa & Lognormal & $\mu, \sigma$ and $\gamma$ & $4.0523,1.3164$ and 0 \\
\hline \multirow{4}{*}{ Anderson-Darling } & Dembi & Lognormal(3P) & $\mu, \sigma$ and $\gamma$ & $2.70,1.64$ and 0.4783 \\
& Dabana & Lognormal(3P) & $\mu, \sigma$ and $\gamma$ & $2.639,2.0503$ and 2.485 \\
& Angar & Normal & $\mu, \sigma$ and $\gamma$ & $52.793,68.0$, and 0 \\
& Wama & Lognormal(3P) & $\mu, \sigma$ and $\gamma$ & $0.96,1.2788$ and 0.2718 \\
& Arjo Didessa & Lognormal & $\mu, \sigma$ and $\gamma$ & $4.0523,1.3164$ and 0 \\
\hline \multirow{4}{*}{ Chi-square } & Dembi & Lognormal(3P) & $\mu, \sigma$ and $\gamma$ & $2.70,1.64$ and 0.4783 \\
& Dabana & Lognormal(3P) & $\mu, \sigma$ and $\gamma$ & $2.639,2.0503$ and 2.485 \\
& Angar & Normal & $\mu, \sigma$ and $\gamma$ & $57.793,68.0$, and 0 \\
& Wama & Pearson 5 & $\alpha, \beta$ and $\gamma$ & $1.0816,1.9942$ and 0 \\
& Arjo Didessa & Lognormal & $\mu, \sigma$ and $\gamma$ & $4.0523,1.3164$ and 0 \\
\hline
\end{tabular}

Note: these parameters are calculated with 12 year data since EasyFit used cannot handle $(>5000)$ data for trial version.

Similarly, using easy fit best distribution is selected as rank of goodness of fit is simulated[35]. The basins annual peak flows were extracted from daily flow hydrograph estimated with ArcSWAT model for each watershed. Logarithm of annual peak flow from each watershed at out let was calculated. The value of average of peak discharge, $\bar{x}$ and standard deviation, $\sigma$ are calculated from estimated flow hydrograph at each outlet of watershed. And the value of $\mathrm{K}_{\mathrm{T}}$ can be calculated for any required return period from equation (6) for lognormal and (7) for logpearson distribution.

\section{1. lognormal distribution}

In lognormal distribution the value of $\mathrm{K}_{\mathrm{T}}$ in equation (4) can be found from equation (5) though equation (6) below where $(\mathrm{f}=$ probability of excedence $=1 / \mathrm{T})$ :

$$
m=\left[\ln \left(\frac{1}{f^{2}}\right)\right]^{1 / 2}(0<f \leq 0.5)
$$


480

481

482

483

484

485

486

487

488

489

490

Then calculating $\mathrm{z}$ using the approximation

$y=K_{T}=m-\frac{2.515517+0.802853 m+0.010328 m^{2}}{1+1.432788 m+0.189269 m^{2}+0.001308 m^{3}}$,

If $\mathrm{f}>0.5,(1-\mathrm{f})$ is replaced for $\mathrm{f}$ in equation (5)

For the lognormal distribution, applied to the logarithms of the variables, and their mean and standard deviation are used in Equation (4). And then antilog of value is taken to get value at treshold.

2. Log Pearson type 3: to use his method, the first step is to take the logarithms of the hydrologic data, $\mathrm{g}=\log (\mathrm{h})$. For $\log$ pearson $\mathrm{K}_{\mathrm{T}}$, is approximated from equation (6) using coefficient of skewness (Cs) and studied by [32] as:

$$
K_{T}=y+\left(y^{2}-1\right) c+\frac{1}{3}\left(y^{3}-6 y\right) c^{2}-\left(y^{2}-1\right) c^{3}+y c^{4}+\frac{1}{3} c^{5}, \text { where, } c=\frac{c_{s}}{6},
$$

Table 10.Expected probable flood with its frequency of occurrence from model determined annual peak

\section{Threshold Values of $\left(X_{\mathrm{T}}\right)$ all units in}

$\mathbf{m}^{3 / s}$

\begin{tabular}{rrlrcc}
\hline $\begin{array}{c}\text { Return } \\
\text { Period }\end{array}$ & \multicolumn{1}{c}{ Angar } & Dembi & Dabana & Wama & $\begin{array}{l}\text { Didessa@ } \\
\text { Confluence of Wama }\end{array}$ \\
\hline 2 & 583.7 & 458.0 & 316.8 & 237.8 & 657.9 \\
5 & 755.5 & 539.8 & 396.9 & 285.7 & 811.6 \\
10 & 864.6 & 594.0 & 446.6 & 317.2 & 913.4 \\
20 & 966.5 & 646.0 & 492.2 & 347.5 & 1011.0 \\
25 & 998.4 & 662.4 & 506.4 & 357.2 & 1042.0 \\
50 & 1095.7 & 713.2 & 549.3 & 387.1 & 1137.4 \\
100 & 1191.1 & 763.6 & 590.9 & 417.3 & 1232.1 \\
200 & 1285.8 & 813.9 & 631.7 & 448.0 & 1326.5 \\
1000 & 1505.4 & 930.2 & 725.1 & 522.3 & 1545.0 \\
10000 & 1825.3 & 1096.5 & 858.1 & 638.4 & 1857.4 \\
\hline
\end{tabular}

All the values are determined at the confluence of reach

According to Arjo Irrigation feasibility of 2007 and 2009 frequency analysis is done for Upper Arjo Didesa at dam site which is approximately same with Dembi watershed. Outlet of Dembi watershed and Dam site is nearer to each other. Hence, Frequency Analysis from simulated flow are compared and found to be similar to that of feasibility study with negligible difference. The estimated 100 years flood was $763.6 \mathrm{~m}^{3} / \mathrm{s}$ and feasibility study estimates as $787 \mathrm{~m}^{3} / \mathrm{s}$. The difference of the value may be the distribution type I used may be different from that feasibility study.

\section{Conclusions}

In this study SWAT model was used as to understand hydrological situation of different watersheds as sources of stream flow has great significance in the effective utilization of water resources. Didessa sub basin has not well studied and understood as compare with the northern sub 
502

503

504

505

506

507

508

509

510

511

512

513

514

515

516

517

518

519

520

521

522

523

524

525

526

527

\section{8}

basins of Blue Nile such as (Tana sub basin). Model assisted hydrological characterization of Didessa sub basin was handled with different hydrological procedures and methods in this study. First the observed metrological and hydrological data were statistically tested and found to be consistent and free of trend. The SWAT Hydrological model for the sub basin was established, calibrated and validated by means of measured daily and monthly discharge at five gauged places in the study area. The calibration and validation of the model were measured by the $\mathrm{R}^{2}$ (coefficient of determination) and the NS (Nash Sutcliff) model efficiency parameter of at monthly and daily time scale. The values of $\mathrm{R}^{2}$ and NS range 0.66 to 0.70 and 0.60 to $0.66,0.66$ to 0.70 and 0.64 to $0.74,0.62$ to 0.80 and 0.61 to 0.8 for Dembi, Arjo Didessa, and Angar tributary watershed respectively, at daily time scale. The values of $R^{2}$ and NS increases at monthly time scale and range 0.80 to 0.86 and 0.72 to $0.83,0.87$ to 0.89 and 0.82 to $0.84,0.82$ to 0.92 and 0.79 to 0.91 for Dembi, Arjo Didessa, and Angar tributary watershed respectively.

Sensitivity analysis realizes parameters those were the most sensitive for the sub basin. And each parameter is arranged based on their sensitivity rank for each watershed as CN2, GWQMN, CH_K, ALPHA_BNK and LAT_TIME are the most sensitive parameters in Didessa sub basin.

Therefore, the hydrological process in Didessa sub basin is characterized using the simulated stream flow at five major tributaries watersheds. This characterization include stream flow hydrograph, identification of sub catchment with highest annual flow, peak flow analysis using fitted probabilistic distribution and unit.

Frequency analysis was performed using the simulated annual peak flood series data sets watersheds of Didesa sub basin. Normal and Lognormal (3P) distribution gives the best fitted probabilistic distribution for most of watersheds except Dembi and Wama watershed. Using these fitted probabilistic distribution the peak flow of the watersheds were computed for 2- 10000 years return period.

Conflicts of Interest: The author declare no conflict of interest

\section{Appendix}
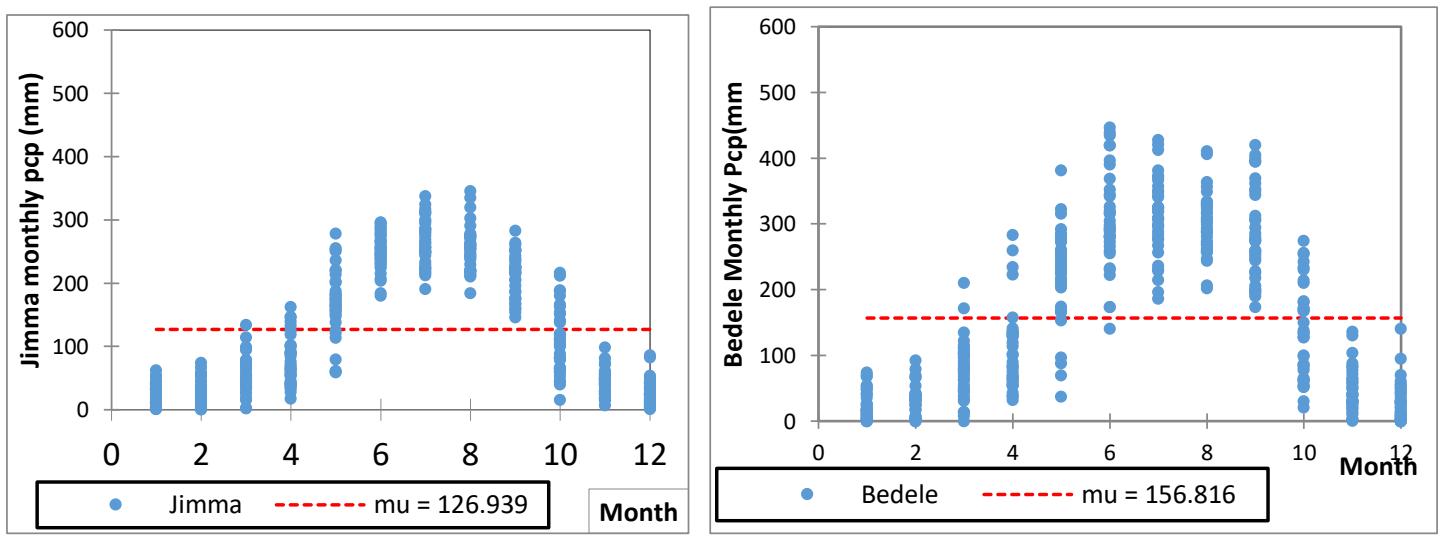

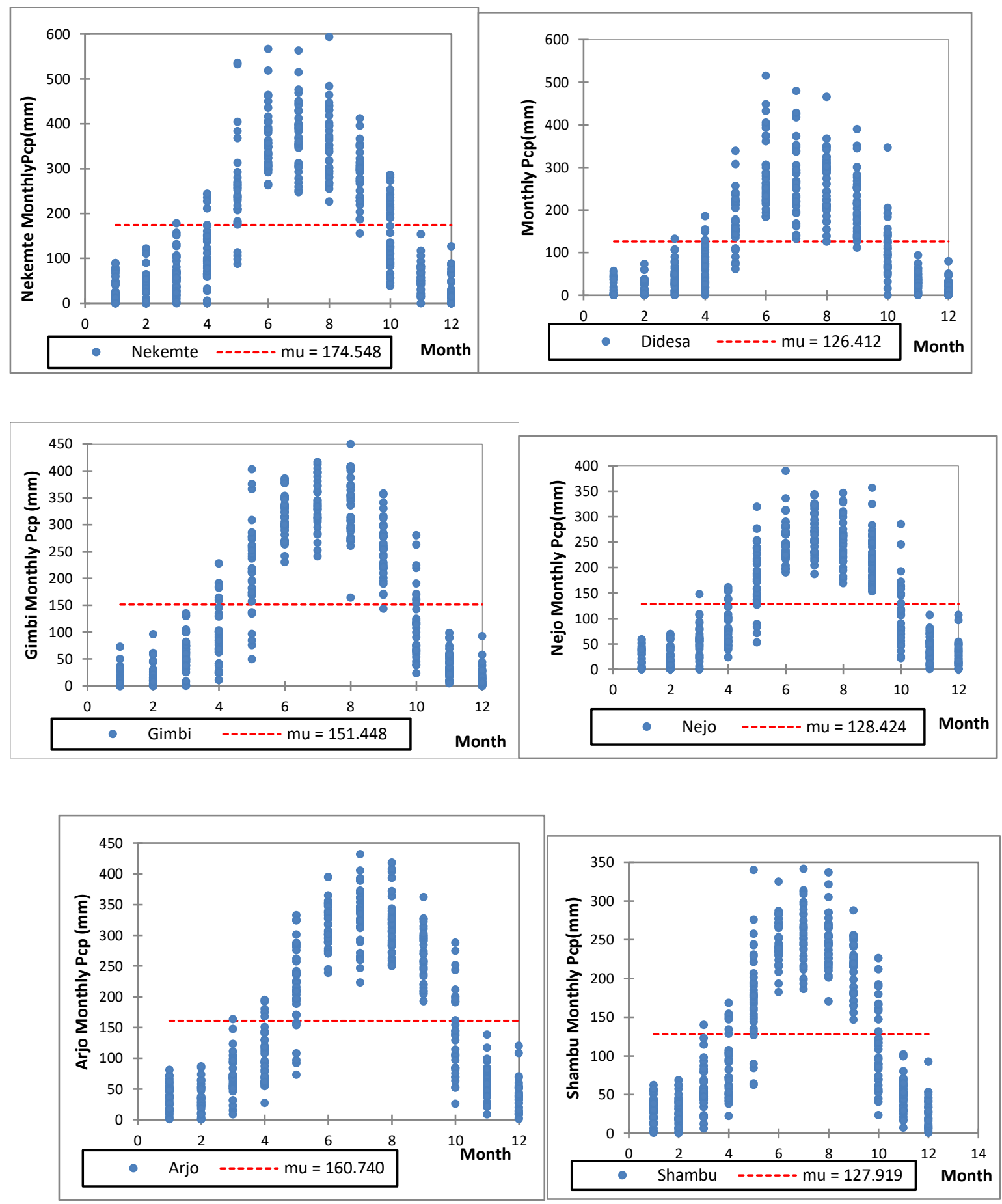

(mu on graph represents mean monthly rainfall of the station). When mu is represented one horizontal line, the series of data has one mean and hence homogeneous.

Figure A1. XLSTAT final output Graphical representation of homogeneity test of rainfall data 
540 Table A1.Parameters' sensitivity Rank at different guaging stations of the sub-basin

\begin{tabular}{|c|c|c|c|c|c|c|c|c|c|c|}
\hline \multirow{2}{*}{ PARAMETER } & \multicolumn{2}{|c|}{ DEMBI } & \multicolumn{2}{|c|}{ ARJO } & \multicolumn{2}{|c|}{ ANGAR } & \multicolumn{2}{|c|}{ DABANA } & \multicolumn{2}{|c|}{ WAMA } \\
\hline & P-value & Rank & P-value & Rank & P-value & Rank & P-value & Rank & P-value & Rank \\
\hline ALPHA_BF & 0.51 & 8 & 0.27 & 4 & 0.42 & 6 & 0.73 & 14 & 0.56 & 10 \\
\hline ALPHA_BNK. & 0.03 & 1 & 0.47 & 9 & 0.84 & 16 & 0.89 & 15 & 0.28 & 6 \\
\hline CH_K2 & 0.53 & 11 & 0.15 & 3 & 0.35 & 4 & 0.27 & 2 & 0.33 & 7 \\
\hline CH_N2 & 0.13 & 2 & 0.88 & 18 & 0.35 & 5 & 0.58 & 12 & 0.51 & 9 \\
\hline CN2.mgt & 0.571 & 13 & 0 & 1 & 0.32 & 3 & 0.51 & 8 & 0.09 & 1 \\
\hline EPCO & 0.4 & 6 & 0.82 & 14 & 0.61 & 10 & 0.96 & 17 & 0.72 & 13 \\
\hline ESCO & 1 & 19 & 0.53 & 10 & 1 & 19 & 1 & 19 & 0.94 & 17 \\
\hline GW_DELAY & 0.82 & 16 & 0.87 & 17 & 0.55 & 9 & 0.5 & 7 & 0.79 & 14 \\
\hline GW_REVAP & 0.131 & 3 & 0.78 & 13 & 0.71 & 12 & 0.4 & 5 & 0.6 & 11 \\
\hline GWQMN & 0.63 & 15 & 0.82 & 15 & 0.19 & 1 & 0.54 & 9 & 0.6 & 12 \\
\hline HRU_SLP & 0.511 & 9 & 0.57 & 11 & 0.86 & 18 & 0.04 & 1 & 0.11 & 2 \\
\hline LAT_TTIME & 0.57 & 12 & 0.13 & 2 & 0.54 & 8 & 0.57 & 11 & 0.18 & 3 \\
\hline OV_N & 0.52 & 10 & 0.95 & 19 & 0.3 & 2 & 0.56 & 10 & 0.21 & 4 \\
\hline RCHRG_DP & 0.61 & 14 & 0.41 & 8 & 0.72 & 13 & 0.92 & 16 & 0.61 & 18 \\
\hline REVAPMN & 0.94 & 17 & 0.27 & 5 & 0.81 & 14 & 0.34 & 3 & 0.86 & 15 \\
\hline SLSUBBSN & 0.45 & 7 & 0.57 & 12 & 0.81 & 15 & 0.5 & 6 & 0.96 & 19 \\
\hline SOL_AWC & 0.96 & 18 & 0.33 & 7 & 0.84 & 17 & 0.6 & 13 & 0.24 & 5 \\
\hline SOL_K & 0.38 & 5 & 0.85 & 16 & 0.51 & 7 & 0.37 & 4 & 0.91 & 16 \\
\hline SURLAG & 0.3 & 4 & 0.28 & 6 & 0.69 & 11 & 0.99 & 18 & 0.34 & 8 \\
\hline
\end{tabular}

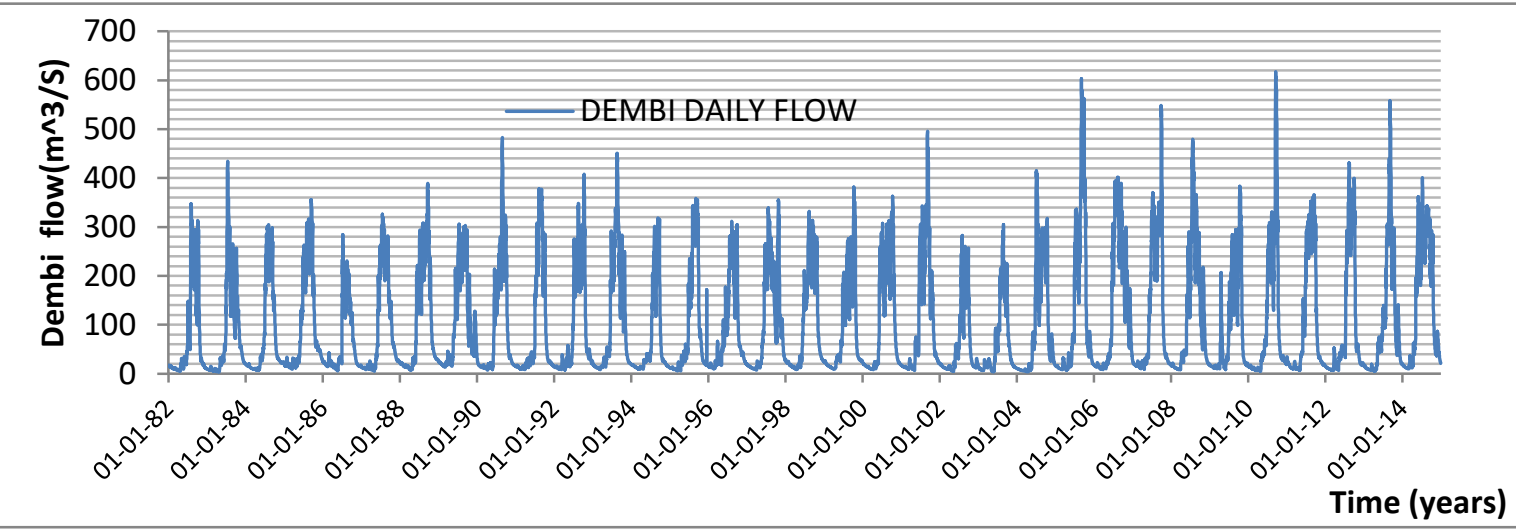

$543 \quad$ (a) 


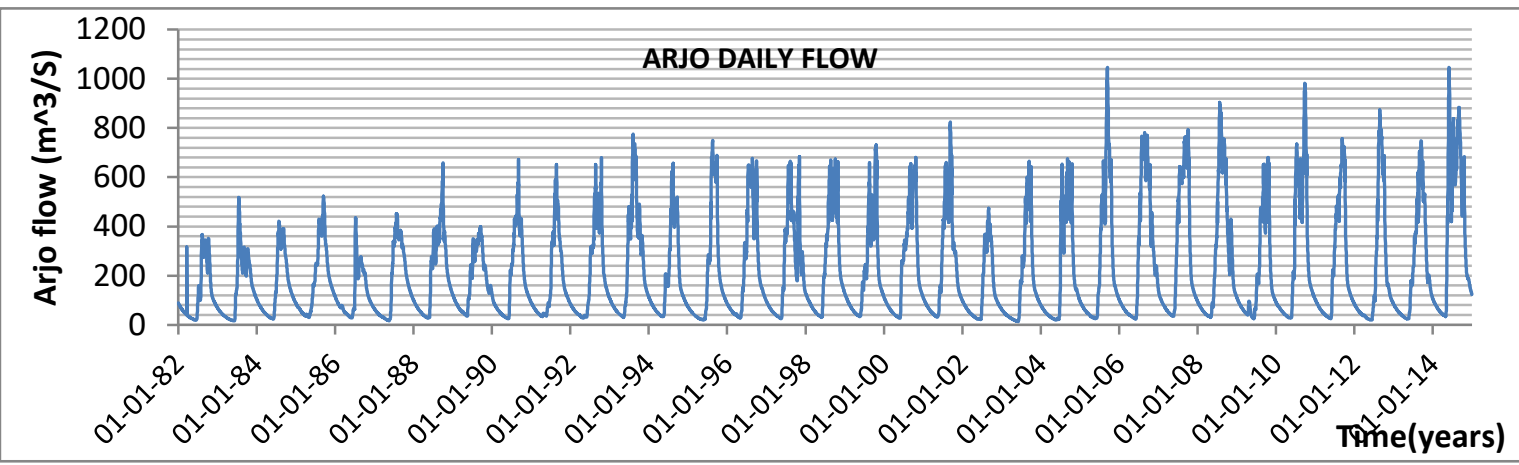

$545 \quad$ (b)

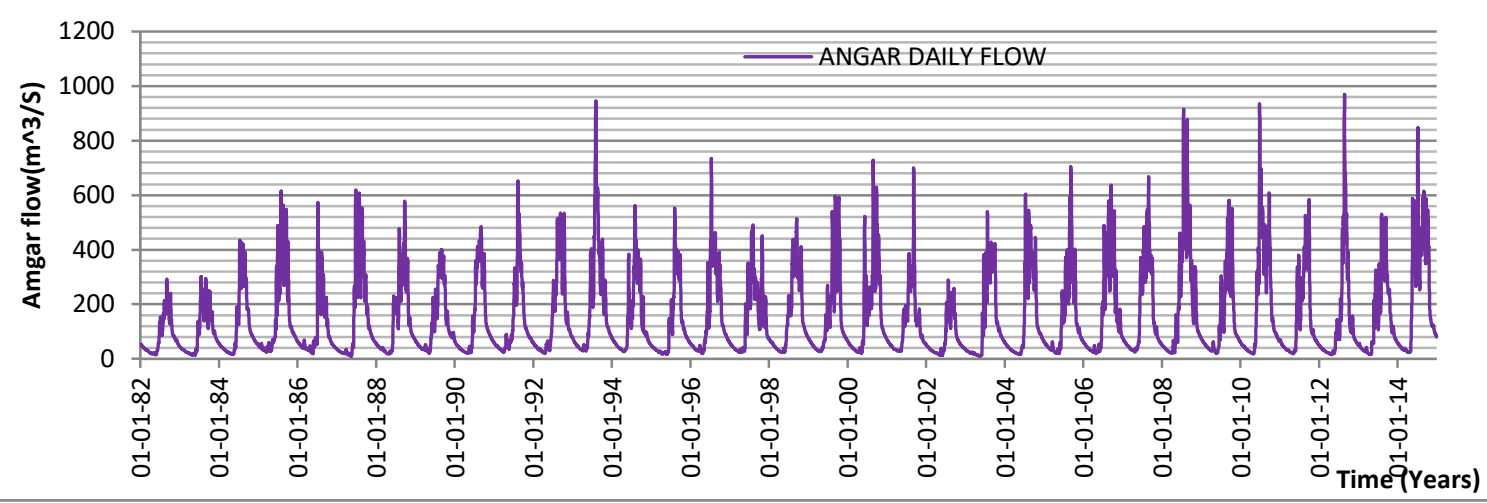

547 (c)

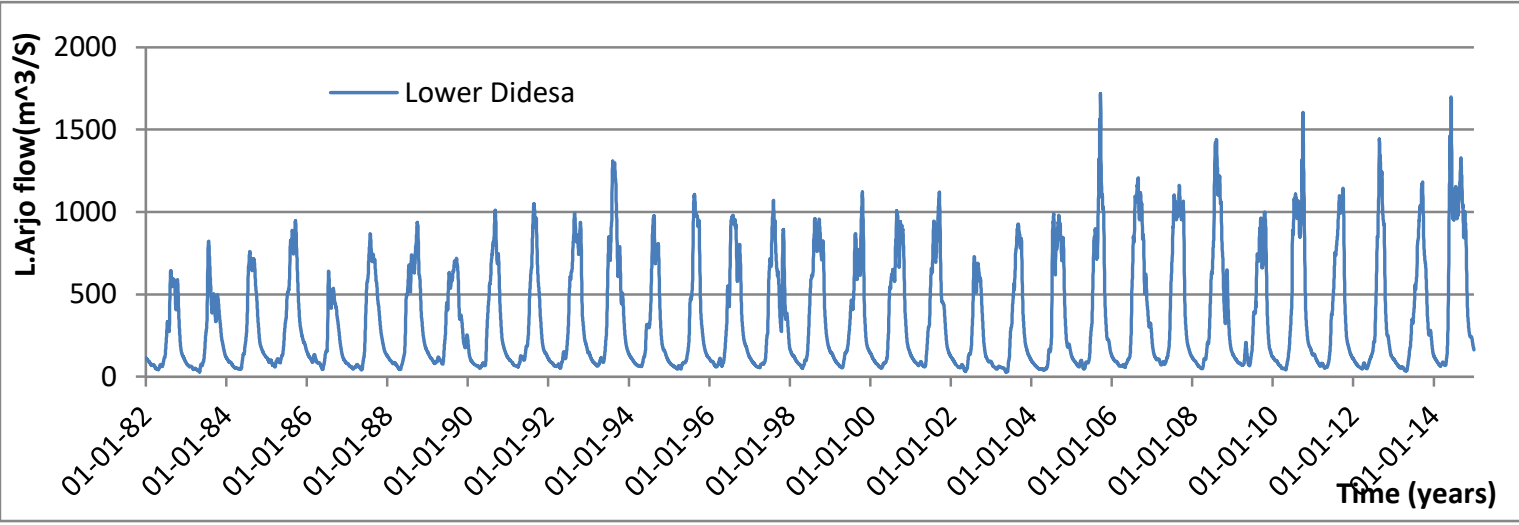

$549 \quad(d)$ 


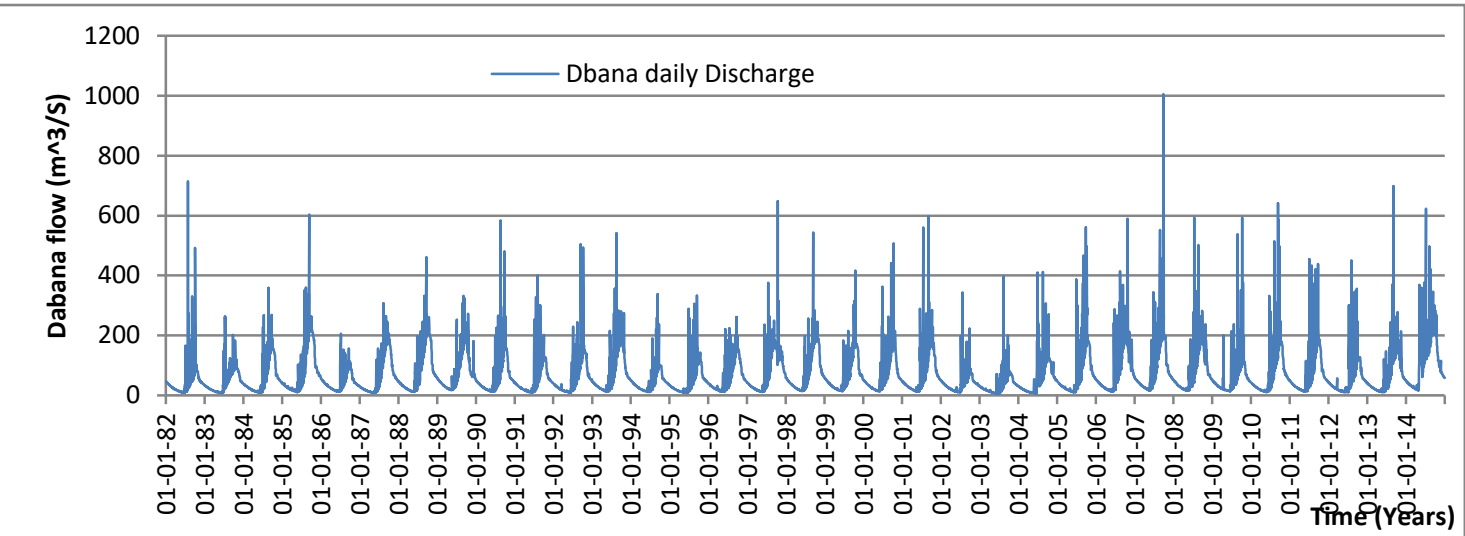

(e)

552 Figure A2. Daily flow Hydrograph: (a) Dembi, (b) Didessa at confluence with Dabana, (c) Angar, (d) Didessa at confluence with Angar, (e) Dabana

\section{References}

1. Tufa, D.F.; Abbulu, Y.E.; Srinivasarao, G.V. Watershed Hydrological Response to Changes in Land Use/Land Covers Patterns of River Basin: A Review. International Journal of Civil, Structural, Environmental and Infrastructure Engineering Research and Development (IJCSEIERD) 2014, 4,157-170.

2. Chang, J.; Zhang, H.; Wang, Y.; Zhu, Y. Assessing the impact of climate variability and human activity to streamflow variation. Hydrol. Earth Syst. Sci.2016, 20, 1547-1560,doi:10.5194/hess-20-1547-2016

3. Fu, G.; Charles, S.P. and Chiew, F.H. A two-parameter climate elasticity of streamflow index to assess climate change effects on annual streamflow.Water Resource. Research 2007,13,p43, doi:10.1029/2007WR005890

4. Conway D. A water balance model of the Upper Blue Nile in Ethiopia. Hydrological sciences journal 1997 Apr 1,42(2),265-86, doi=10.1.1.399.6328

5. Gebrekristos, S. T. Understanding Catchment Processes and Hydrological Modelling in the Abay/Upper Blue Nile Basin,TU Delft, The Netherlands, 2015.

6. Tekleab, S.; Uhlenbrook, S.; Mohamed, Y.; Temesgen, M.; Savenije, H.H.; Wenninger, J. Water balance modeling of Upper Blue Nile catchments using a top-down approach. Hydrol. Earth Syst. Sci.2011,15(7),2179-2193,doi:10.5194/hess-15-2179-2011

7. DeFries, R.; Eshleman, K.N. Land-use change and hydrologic processes: a major focus for the future. Hydrol. Process.,2004, 18(11), 2183-2186,doi:10.1002/hyp.5584

8. Ali, H.; Descheemaeker, K.; Steenhuis, T.S.; Pandey, S. Comparison of landuse and landcover changes, drivers and impacts for a moisture-sufficient and drought-prone region in the Ethiopian highlands. Exp. Agric.2011, 47, 71-83,doi: 10.1017/S0014479710000840.

9. Zeleke, G.; Hurni, H. Implications of land use and land cover dynamics for mountain resource degradation in the Northwestern Ethiopian highlands. Mt. Res. Dev. 2001,21, 184- 191.

10. Sivapalan, M.; Blöschl, G.; Merz, R.; Gutknecht, D. Linking flood frequency to long term water balance: incorporating effects of seasonality. Water resource research 2005, 41(6),1-17,doi:10.1029/2004WR003439

11. Berhanu, B.; Seleshi, Y.; Demisse, S.S.; Melesse, A.M. Flow Regime Classification and Hydrological Characterization: A Case Study of Ethiopian Rivers. Water 2015 , 7(6), 3149-3165; doi:10.3390/w7063149

12. Arnold, J.G.; Srinivasan, R.; Muttiah, R.S.; Williams, J.R. Large-area hydrologic modeling and assessment. Part I. Model development. J. American Water Res. Asso. 1998, 34(1): 73-89.

13. McDonnell, J.J.; Sivapalan, M.; Vaché, K.; Dunn, S.; Grant, G.; Haggerty, R.; Hinz, C.; Hooper, R.; Kirchner, J.; Roderick, M.L.; Selker, J. Moving beyond heterogeneity and process complexity: A new vision for watershed hydrology. Water Resources Research 2007 Jul 1,43(7).

14. Saxena, R. K.; Verma, K. S.; Chary, G. R.; Srivastava, R.; and Barthwal, A. K. IRS-1C data application in watershed characterization and management. Int. J. Remote Sens 2000. 21(17), 3197-3208. 
15. Muluneh, T.; Mamo, W. Morphometric Analysis of Didessa River Catchment in Blue Nile Basin, Western Ethiopia. Science, Technology and Arts Research Journal 2014, 3(3): 191-197.

16. Berhanu,B.;Melesse,A.M.;Seleshi,Y. GIS-based hydrological zones and soil geo-database of Ethiopia. Catena 2013, $104,21-31$

17. Golmohammadi,G.;Prasher,S.; Madani,A.; Rudra,R. Evaluating Three Hydrological Distributed Watershed Models: MIKE-SHE, APEX, SWAT. Hydrology 2014, 1(1), 20-39; doi:10.3390/hydrology1010020

18. Corona,J.A.; Lakhankar,T.; Pradhanang,S.; Khanbilvardi,R. Remote Sensing and Ground-Based Weather Forcing Data Analysis for Stream flow Simulation. Hydrology 2014, 1, 89-111; doi:10.3390/hydrology1010089

19. Dhungel,R.; Fiedler ,F. Water Balance to Recharge Calculation: Implications for Watershed Management Using Systems Dynamics Approach. Hydrology 2016, 3(1), 13; doi:10.3390/hydrology3010013

20. Zemke,J.J. Runoff and Soil Erosion Assessment on Forest Roads using a Small Scale Rainfall Simulator. Hydrology 2016, 3(3), 25; doi:10.3390/hydrology3030025

21. Akpoti,K.; Antwi,E.O.; Kabo-bah,A.T. Impacts of Rainfall Variability, Land Use and Land Cover Change on Stream Flow of the Black Volta Basin, West Africa. Hydrology 2016, 3(3), 26; doi:10.3390/hydrology3030026

22. Rafiei Emam, A.; Kappas,M.; Linh,N.H.; Renchin,T. Hydrological Modeling and Runoff Mitigation in an Ungauged Basin of Central Vietnam Using SWAT Model. Hydrology 2017, 4, 16; doi:10.3390/hydrology4010016

23. Sith,R.; Nadaoka,K. Comparison of SWAT and GSSHA for High Time Resolution Prediction of Stream Flow and Sediment Concentration in a Small Agricultural Watershed. Hydrology 2017, 4, 27; doi:10.3390/hydrology4020027

24. Kendall M. Multivariate analysis. Charles Griffin, $\mathbf{1 9 7 5}$

25. Hirsch, R.M.; Slack, J.R. A nonparametric trend test for seasonal data with serial dependence. Water Resources Research 1984 Jun 1, 20(6):727-32.

26. Mann, H.B. "Nonparametric tests against trend. Econometrica: Journal of the Econometric Society 1945, 245259, DOI: $10.2307 / 1907187$

27. Arnold, Jeffrey, G. et al. SWAT: Model use, calibration, and validation. Transactions of the ASABE 55.4 2012,1491-1508.

28. Mengistu, D.T.; Moges, S.A.; Sorteberg,A. Retraction Notice. Journal: Journal of Water Resource and Protection, 2016, 8(1).

29. Abromowitz, M.; Stegun, I.A. Handbook of mathematical functions. NBS (now NIST). 1965 Dec.

30. Lenhart, T.; Eckhardt, K.; Fohrer, N.; Frede, H.G. Comparison of two different approaches of sensitivity analysis. Physics and Chemistry of the Earth, Parts A/B/C 2002 Dec 31, 27(9):645-54.

31. Awulachew, S.B.; Yilma, A.D.; Loulseged, M.; Loiskandl, W.; Ayana, M.; Alamirew, T. Water resources and irrigation development in Ethiopia. Iwmi; 2007.

32. Kite, G.W. Frequency and risk analyses in hydrology. Water Resources; 1977.

33. Lehner, B.; Döll, P.; Alcamo, J.; Henrichs, T.; Kaspar, F. Estimating the impact of global change on flood and drought risks in Europe: a continental, integrated analysis. Climatic Change 2006 Apr 1, 75(3),273-99.

34. Apipattanavis, S.; Rajagopalan, B.; and Lall, U. Local polynomial-based flood frequency estimator for mixed population. Journal of Hydrologic Engineering 2010, 15(9), 680-691.

35. Gebremariam, S.Y.; Martin, J.F.; DeMarchi,C.;Bosch, N.S; Confesor, R.; Ludsin, S.A. A comprehensive approach to evaluating watershed models for predicting river flow regimes critical to downstream ecosystem services. Environmental modelling \& software 2014 Nov 30,61,121-34.

36. BCEOM, 1998. Abbay River Basin Integrated Development Master Plan Project. Report to Ministry of Water Resources, The Federal Democratic Republic of Ethiopia

37. Tolson, B.A.; Shoemaker, C.A. Dynamically dimensioned search algorithm for computationally efficient watershed model calibration. Water Resour. Res. 2007, 43, 1-16.

38. Nash, J.E.; Sutchliffe, J.V. River flow forecasting through conceptual models. Part 1-A discussion of principles.J. Hydrol. 1970, 10, 282-290.

39. Krause, P.; Boyle, D.P.; Base, F. Comparision of different efficiency criteria for hydrological model assessment. Adv. Geosci. 2005, 5, 83-87. 
40. Moriasi, D. N.; Arnold, J. G.; Van Liew, M. W.; Bingner, R. L.; Harmel, R. D.; Veith, T. L. Model evaluation guidelines for systematic quantification of accuracy in watershed simulations. Transactions of the ASABE2007, 50, 885-900.,http://dx.doi.org/10.13031/2013.23153

41. Gupta, H. V.; Sorooshian, S.; and Yapo, P.O. Status of automatic calibration for hydrologic models: Comparison with multilevel expert calibration. J. Hydrologic Eng1999, 4(2),135-143

42. Santhi, C.; Arnold, J.G.; Williams, J.R.; Dugas, W.A.; Srinivasan, R.; Hauck, L.M. Validation of the SWAT model on a large river basin with point and nonpoint sources. J. Am. Water Res. Assoc. 2001, 37, 1169-1188.

43. Van Liew, M.W.; Garbrecht, J. Hydrological simulation of the little Washita river experimental watershed using SWAT. J. Am. Water Res. Assoc. 2003, 39, 413-426.

44. Gassman, P.W.; Reyes, M.R.; Green, C.H.; Arnold, J.G. The soil and water assessment tool: Historical development, application, and future research directions. Trans. ASABE 2007, 50, 1211-1250.

45. Neitsch, S.L.; Arnold, J.G.; Kiniry, J.R.; Williams, J.R. Soil and Water Assessment Tool: Theoretical Documentation-Version 2009; Grassland, Soil and Water Research Laboratory, Agricultural Research Service:College Station, TX, USA, 2009; p. 618.

46. Chow, V.T.; Maidment, D.R.; Mays, L.W. Applied Hydrology; McGrawHill: New York, NY, USA, 1998.

47. Fesea, B. (Oromia Water Work Design and Supervision Enterprise, Addis Ababa, Oromia, Ethiopia). Personal communication, 2017.

48. Alexanderson, G.L.; Wetzel, J.E.; A simplicial 3-arrangement of 21 planes. Discrete mathematics 1986 Jun 1,60,67-73.

49. Abbaspour KC, Vejdani M, Haghighat S, Yang J. SWAT-CUP calibration and uncertainty programs for SWAT. InMODSIM 2007 International Congress on Modelling and Simulation, Modelling and Simulation Society of Australia and New Zealand 2007 Dec (pp. 1596-1602).

50. Moriasi, D. N., J. G. Arnold, M. W. Van Liew, R. L. Binger, R. D. Harmel, and T. Veith. 2007. Model evaluation guidelines for systematic quantification of accuracy in watershed simulations. Trans. ASABE 50(3): 885-900.

51. Rouholahnejad E, Abbaspour KC, Srinivasan R, Bacu V, Lehmann A. Water resources of the Black Sea Basin at high spatial and temporal resolution. Water Resources Research. 2014 Jul 1; 50(7):5866-85.

52. Singo,L.R; Kundu,P.M.; Odiyo,J.O.; Mathivha,F.I. and Nkuna,T.R. Flood Frequency Analysis of Annual Maximum Stream Flows for Luvuvhu River Catchment. https://www.researchgate.net/publication/293605685

53. Mehrannia, H.\& Pakgohar,A. USING EASY FIT SOFTWARE FOR GOODNESS-OF-FIT TEST AND DATA GENERATION. International Journal of Mathematical Archive-5(1), 2014, 118-124 